\title{
CB Research Square \\ Comparison of Chemical Compounds and Their Influence on The Taste of Coffee Depending on Green Beans Storage Conditions
}

\author{
Magdalena Zarebska ( $\nabla$ magdalena.zarebska@icso.lukasiewicz.gov.pl ) \\ The Łukasiewicz Research Network - Institute of Heavy Organic Synthesis "Blachownia" \\ Natalia Stanek \\ The Łukasiewicz Research Network - Institute of Heavy Organic Synthesis "Blachownia" \\ Krzysztof Barabosz \\ Przedsiebiorstwo Handlowo Usługowe P.A.R.K. Katarzyna Porada
}

Anna Jaszkiewicz

The Łukasiewicz Research Network - Institute of Heavy Organic Synthesis "Blachownia"

Renata Kulesza

The Łukasiewicz Research Network - Institute of Heavy Organic Synthesis "Blachownia"

Rafał Matejuk

Przedsiebiorstwo Handlowo Usługowe P.A.R.K. Katarzyna Porada

Dariusz Andrzejewski

Opole University of Technology

Łukasz Biłos

Opole University of Technology

Artur Porada

Przedsiebiorstwo Handlowo Usługowe P.A.R.K. Katarzyna Porada

\section{Research Article}

Keywords: green coffee (GC), HPLC, (GrainPro (G), roasted coffee (RC)

Posted Date: May 26th, 2021

DOI: https://doi.org/10.21203/rs.3.rs-547987/v1

License: @ (i) This work is licensed under a Creative Commons Attribution 4.0 International License. Read Full License

Version of Record: A version of this preprint was published at Scientific Reports on February 17th, 2022. See the published version at https://doi.org/10.1038/s41598-022-06676-9. 


\section{Abstract}

Currently, there is no technology for storing green coffee (GC), which results in obtaining high-quality roasted coffee (RC). The aim of this study was evaluating the effects of storage temperature $\left(-10,5,10,18,20^{\circ} \mathrm{C}\right.$, uncontrolled), post-harvest treatment method (natural $(\mathrm{N})$, washed $(\mathrm{W})$ ) and type of packaging material (GrainPro $(\mathrm{G})$, jute $(\mathrm{J})$ bags) on content of chlorogenic acids, caffeine and trigonelline as also on sensory profile of GC from "specialty' sector after 12 months of measured storage. HPLC results showed that GrainPro bags preserve considered compounds better than jute. Exception was $10 \circ \mathrm{C}$ chamber, where in the samples from jute have been reported higher contents of all analyzed compounds. Also natural way of grain processing retains more assayed compounds. The best results were obtained in $10^{\circ} \mathrm{C}$ for jute both, natural and washed, where the highest level of all considered compounds were noted. The tendency was supported by the sensory analysis.

\section{Introduction}

The coffee is one of the most widely consumed products in the world. In 2018/2019 season, global coffee production reached 170.22 million (60-kilo) bags and this quantity was $4.6 \%$ higher than in the previous season $2017 / 2018$. The production of Arabica was about 100 while Robusta 70 million bags [1]. Since improving the cup quality and changing coffee image by the propagation of information about its health benefits, the coffee consumption has increased significantly. People are more and more conscious about what they consume and want to know where the coffee is coming from, what is its origin, how it was roasted [2]. The roasteries have noticed this trend and they are bringing out their special coffee products.

Generally not all beans can be used as a high quality coffee. According to the Specialty Coffee Association of America (SCAA), coffee with total score 80 points or more in a sensory analysis is classified as "specialty" [3]. The judges are assessing important flavour attributes for coffee: aroma, flavour, aftertaste, acidity, body, balance, uniformity, clean cup, sweetness and defects according to the Cupping Specialty Coffee Protocol. Specialty Coffee market is quite a young compared to the entire coffee market in the world. It is distinguished by the approach to the raw material, which is both the coffee plantation, and green and roasted bean. At every stage of production, from cultivation to the cup of brewed coffee everything takes place under controlled conditions. The coffee tree grows only in rural areas, it is harvested only by hand, so that only ripe cherries are picked. Then the cherries are processed carefully and under controlled conditions by various methods e.g. natural (dry, when entire cherry is first cleaned and then dried) and washed (wet, when the fruits covering the beans are removed prior to drying). Afterwards the beans are dried to the appropriate level of humidity, and then transported to their destination, i.e. a coffee roastery where the coffees are roasted in an craft way to bring out the full aroma and flavour. The recipients of such beans are specialty cafes that have perfected the entire process of coffee cup preparing. The specialty coffee is distinguished by its full aroma, unique flavour but also by its chemical composition. [4, 5]. Sanmiguel, Torrez \& Pérez-Villarreal indicated that over the last decade, consumer interest in the behavior and sensory attributes of coffee has increased significantly [6]. Also Barahona, Sanmiguel \& Yang show the relationship between the sensory attributes of coffee beverages and the price of coffee [7].

Few years ago, consumers perceived coffee mainly as a stimulant, today they are informed about beneficial components and suggested health benefits. Regular coffee drinkers are less likely to suffer from a range of chronic and degenerative diseases (e.g. cancer, cardiovascular disorders, diabetes and Parkinson's), than people who do not drink coffee $[8,9,10]$. The positive health effects of coffee consumption are attributed to the presence of caffeine, trigonelline and chlorogenic acids [11]. Caffeine is the most widely consumed psychoactive substance worldwide that has many biological effects: stimulant and allowing for maintained cognitive function [12]. Trigoneline is the second most predominant alkaloid in raw coffee beans. The roasting of coffee beans converts trigonelline to nicotinic acid, a water-soluble B vitamin also known as niacin. Trigoneline appears to have several biological activities: as an antimicrobial agent and regenerates of dendrites and axons in cortical neurons [13]. Moreover, trigonelline may indirectly effects on hypoglycemic and hypolipidemic [14]. Various studies indicate that coffee has the high concentrations of polyphenols $[15,16,17]$. The most studied polyphenols in coffee are chlorogenic acids. The 3-0-caffeoylquinic acid is thought to be the most abundant among of its isomers in coffee $[18,19]$. Chlorogenic acids are considered to have a positive effect on the prevention of diabetes and in the treatment of its symptoms [20].

Harvesting processes, roast degree and conditions of GC beans storage are responsible for the production or degradation of several compounds, which give sensory characteristics to the coffee beverage [19]. Keeping coffee fresh is critical to preserving taste. 
During inappropriate GC beans storage, there is decrease in the quality and level of chemical compounds, which is expressed by flattening of cup quality. During 12 months storage, Król, Gantner, Tatarak, \& Hallmann [17] noticed degradation of polyphenolic compounds. Coradi, Borem, Saath, \& Marques [21] noticed that washed coffee presents better quality when compared to the product in its natural form. While, high temperatures and high water content have been reported as the main factors causing sensory changes in coffee during storage $[22,23,5]$.

GC beans spend a lot of time in storage before they reach the consumer. The literature indicates $[24,25,26]$ that the storage conditions of raw beans are an important parameter influencing the quality of coffee beverages, but there is a lack of studies about optimal conditions of GC storage and their influence on the sensory characteristic and chemical composition in coffee. Ensuring that the storage areas have optimal conditions helps preserve the rich taste, safety and quality of GC beans. Due to the long time and high transport cost of coffees from the specialty sector, preservation of the chemical compounds presented in GC beans, seems to be crucial for specialty coffee roasters and for consumers who get used to the taste of coffee. That is why more coffees are contracted for 12 and even up to 24 months, because coffee from the same plantation may taste different in the next harvest. Finding the best storage conditions may not only slow down the degradation process of the bean, but also it could be the driving force behind the construction of a central, fully controlled warehouse for more than one coffee roaster. The central storage will also allow for consolidated purchases of raw material, which can be beneficial for both, farmer and the roaster. Therefore, in this study we have evaluated the influence of GC beans storage conditions on the chemical composition and cup quality. The GC beans were stored from 12 months in measured chambers at various temperatures $\left(-10,5,10,18,20^{\circ} \mathrm{C}\right.$ and uncontrolled, UC) and different packaging (polypropylene-GrainPro and natural fiber-jute) to determine their quality attributes, including taste loss during storage and level of caffeine, trigonelline and chlorogenic acids. It also seemed important to show the differences in the chemical composition of GC and RC brews as currently in many countries, including Poland, the GC brews become very popular as antiobesity drinks [27]. The need to find the best temperature and type of packaging during GC beans storage which can allow to maintain high properties of green and hence roasted grain, is therefore legitimate.

\section{Methods}

\section{Coffee samples}

GC beans were delivered from Finca El Oregano (1700 masl)-natural processed coffee and Finca La Maravilla (1850 masl)-washed processed coffee, plantations located in Huehuetenango, Guatemala. Both type of coffees were drying until an $11 \%$ (wb) moisture and sealed in GrainPro and jute bags. After 5 months from harvesting coffees arrived in Poland by sea.

\section{Reagents}

Analytical standards of chlorogenic acid (3-CQA, CAS:327-97-9), neochlorogenic acid (5-CQA, CAS: 906-33-2), caffeine (CAS: 58-082), trigonelline (CAS: 535-83-1) were purchased from Sigma-Aldrich, Fluka, Chromadex. All standards used were of analytical grade ( $\geq 99 \%$ purity). The mobile phase was prepared by diluting formic acid (Fisher Scientific, LC-MS purity, CAS: 64-18-6) with ultrapure water (Direct-Q system, resistivity below $18 \mathrm{M} \Omega \mathrm{cm}$ ) to a concentration of $0,1 \%(\mathrm{w} / \mathrm{w})$ and $\mathrm{pH}$ was adjusted to 2.4. The solution was filtered under vacuum system through a 0,45 $\mu \mathrm{m}$ filter. The The second part of the mobile phase was methanol (POCH, HPLC grade, CAS: 67-56-1). Stock solutions of $1000 \mathrm{mg} / \mathrm{l}$ were prepared by diluting each analyzed compound in HPLC grade methanol. These solutions were diluted in methanol to reach the intermediate concentrations. All solutions were stored in the fridge in $4^{\circ} \mathrm{C}$.

\section{Coffee storage}

After arrival to Poland, GC beans were divided into the $100 \mathrm{~g}$ samples and packed separately in small $\mathrm{G}$ and $\mathrm{J}$ bags. In this form they were stored in measured chambers at various temperatures $\left(-10,5,10,18,20^{\circ} \mathrm{C}\right.$ and uncontrolled) during 12 months. The humidity level was set to be kept at $50 \%$ relative humidity $(\mathrm{RH})$ except $-10^{\circ} \mathrm{C}$ chamber it was $39 \% \mathrm{RH}$.

\section{Roasting}

After 12 months storage, GC beans samples were removed from all measured chambers for stabilization. Half of them were used for further chemical analysis while the corresponding other half was roasted after day of stabilization. Sample roaster ROEST S100 designed for optimal workflow and efficiency in a coffee lab maintained the following conditions: roasting start temperature: $165^{\circ} \mathrm{C}$, 
final temperature: $205^{\circ} \mathrm{C}$, roasting time: 6-7 min with fixed airflow and heater setting, development time: 53 seconds. Then, RC beans were subjected to sensory and chemical analysis.

\section{Extraction}

The samples of GC and RC were ground (Blender type GB25, Hamilton Beach Commercial, USA). Then, $0.5 \mathrm{~g}$ of milled beans were extracted by $15 \mathrm{ml}$ of distilled water $\left(90^{\circ} \mathrm{C}\right)$ on a shaker (Multi-Tube Vortexer, Benchmark, USA) for $10 \mathrm{~min}(500 \mathrm{rpm})$. Further, the sample solution was filtered using $0.45 \mu \mathrm{m}$ nylon with glass pre-filter (GF/NY, PureLand) before analysis. Extraction of each sample was performed in triplicates.

\section{HPLC analysis}

The chromatographic analysis was performed on Dionex UltiMate 3000 chromatograph equipped with and automatic pump, injector, autosampler, column compartment, UV-VIS detector with photodiode array technology (PDA). Instrument control, data acquisition and processing were managed by Chromeleon 6.8 software. Compounds were separated with isocratic reverse-phase system. A $100 \times 4.6 \mathrm{~mm}$ chromatographic column Kinetex XB C18 with iso-butyl side chains and with TMS endcapping stationary phase $\left(3,5 \mu \mathrm{m}\right.$, Phenomenex) and the guard column with similar composition were employed. $30^{\circ} \mathrm{C}$ was monitored in column compartment during all chromatographic runs. The mobile phase consisted of formic acid solution in water $(0.1 \%, w / w)$ as a solvent $A$ and methanol as a solvent $B$. The elution conditions were: $85 \%$ A and $15 \%$ B ( $0-12$ min). During all analysis time, the flow rate of the mobile phase remained at the level of $1.0 \mathrm{ml} / \mathrm{min}$ and injection volume was $1 \mu \mathrm{l}$. The wavelengths scanned were $325 \mathrm{~nm}$ for 3-CQA, 4-CQA, 5-CQA and $272 \mathrm{~nm}$ for caffeine and trigonelline.

\section{Sensory analysis}

The sensory evaluation of coffee samples was performed using scaling method described by the SCAA (2015). Five certified judges in two independent cupping evaluated seven sensorial attributes (aroma, flavour, aftertaste, acidity, body, balance and overall impression). The GC samples were roasted 48 hours before the cupping, ground immediately prior to cupping, no more than 15 minutes before water infusion. The hot water $\left(97^{\circ} \mathrm{C}\right)$ was poured directly into the measured grounds to the rim of the cup. The steeping time took 4 minutes before evaluation process started.

\section{Statistical analysis}

All HPLC results in the study were expressed as mean from three independent replicates measured in duplicate $(n=6) \pm$ standard deviation. While for sensory analysis, results from 5 cuppers in 2 independent cupping using triangulation were used and also expressed as mean $(n=10) \pm$ standard deviation. Classification techniques, such as: cluster analysis (CA, tree diagram using Ward's method with Euclidean distance) and principal component analysis (PCA) were used to interpret the obtained results. The calculations were performed using the software STATISTICA ver. 10. Correlation matrix was used to find significant correlation between considered variables. Differences were considered significant when $p<0.05$.

\section{Results And Discussion}

\section{HPLC analysis- Characterization of chlorogenic acids, caffeine and trigonelline}

This part aims to separate, identify and quantify important for coffee extracts substances, especially two groups. The first are polyphenolic acids, namely, chlorogenic acids such as 3-CQA, 4-CQA, 5-CQA and alkaloids of which caffeine and trigonelline are the key components. The level of identified compounds is shown in Table 1. Content of these ingredients differ in GC and RC beans and depends on the number of factors, such as e.g. post-harvest techniques, storage temperature and type of bags [28, 29] separation, identification and quantification of mentioned compounds were carried out using high-performance liquid chromatography with diode array detection (HPLC-DAD). For confirmation, UV-VIS absorption spectrum for each compound in coffee samples was compared with corresponding standard spectrum (Fig. 1). Identification of individual compounds was made by comparing individual retention times of each compound peak obtained during the chromatographic analyze of the coffee samples with retention time of the corresponding standards. The content of the compounds was calculated based on five points calibration curve. Each point was injected in duplicate. Identification and quantification of studied compounds were perform using the 
validated methodology confirmed its selective, linear, precise, and accurate character. Validation parameters and chromatographic data are shown in Table 2.

CQA profiles were significantly different among all experiment variants of temperature, type of packaging and grain processing. For GC samples after 12 months storage, 4-CQA (RDS 16\%) and 5-CQA (RDS 15\%) presented the highest diversity while in RC samples all compounds maintained at a similar level of diversity (RDS about 10\%). 3-CQA was the predominant analyzed compound in GC samples corresponding to approximately 55-60\%. Trigonelline and caffeine were 17 and $15 \%$ respectively while 4-CQA and 5-CQA constituted only 7 and $5 \%$ of analyzed ingredients. In RC samples, 3-CQA level lowered and corresponded to about $30 \%$ among the analyzed compounds and also was predominant. Trigonelline and caffeine remained the same level of 21\%, while 4-CQA and 5-CQA constituted 13 and $10 \%$ respectively. Figure 2 shows the difference in analyzed compounds in GC and RC samples after 12 months storage. The highest level of caffeine and trigonelline for GC and RC, was found in JN samples stored in 10oC (about 1150 and $1300 \mathrm{mg} / 100 \mathrm{~g}$ respectively), and the lowest in $\mathrm{GW}$ and $\mathrm{JW}$ in $-100 \mathrm{C}$ (about 840 and $960 \mathrm{mg} / 100 \mathrm{~g}$ respectively). There were no significant differences between these compounds in all experiments of GC and RC extracts $(p<0.05)$. Despite the fact that in the JN bags in uncontrolled conditions and GN 180C, content of the caffeine and trigonelline in roasted coffee was equally high (about 1200 and $1300 \mathrm{mg} / 100 \mathrm{~g}$ respectively), a much lower content of these compounds in GC samples was noted (about 950 and 1100 $\mathrm{mg} / 100 \mathrm{~g}$ respectively) and thus, there was more variation between $\mathrm{GC}$ and $\mathrm{RC}$ samples.

Roasting of GC caused loss of the water inside coffee beans and then volatile compounds and carbon dioxide are formed. In general extracting of caffeine and trigonelline from RC is easier than from GC thus, higher level of these compounds were found in $\mathrm{RC}$ samples what is in accordance with [30, 31, 32].

CQAs content slowly decreased in GCs among different variants of temperature, type of packaging and grain processing. After 12 months storage, the smallest differences in the content of CQAs were noted in the chambers $10^{\circ} \mathrm{C}$ for $\mathrm{J}$ both, $\mathrm{N}(1 \%$ of difference from initial concentration-DFIC) and W (2\% DFIC). While the greatest decrease was recorded in the chamber $5^{\circ} \mathrm{C}$ for both $\mathrm{J}$ bags, $\mathrm{N}$ (49\% DFIC) and W (59\% DFIC) as well. A similar relationship was observed for caffeine and trigonelline content.

For RC prepared from GC after 12 months storage, the smallest content variation for CQAs was observed in chamber $10^{\circ} \mathrm{C}$ for $\mathrm{JW}$ ( $1 \%$ DFIC), $18^{\circ} \mathrm{C}$ for both natural, GrainPro (4\% DFIC) and jute (5\% DFIC). This time the biggest difference from initial concentration was noted in the chamber $-10^{\circ} \mathrm{C}$ for $\mathrm{JW}(42 \% \mathrm{DFIC})$ and in $20^{\circ} \mathrm{C}$ for $\mathrm{JN}(48 \% \mathrm{DFIC})$. One more time, the same was recorded for the quantity of caffeine and trigonelline.

At the end of 12 months of storage, the sum of CQAs, caffeine and trigonelline contents of GC in washed samples were noted to be lower than in the GC samples prepared in natural process, while for RC prepared from GC after mentioned time of storage the situation was quite the opposite for CQAs (except stored in $18^{\circ} \mathrm{C}$ ) and for caffeine (except stored in $-10^{\circ} \mathrm{C}, 18^{\circ} \mathrm{C}$ and uncontrolled conditions). These trends in trigonelline content in RC brews were the same as in GC samples.

The results show, that for both, $\mathrm{N}$ and $\mathrm{W}$ coffee samples, $\mathrm{G}$ bag can preserve CQAs, caffeine and trigonelline in $\mathrm{GC}$ beans better than $\mathrm{J}$ bag during storage time. The exception is chamber $10^{\circ} \mathrm{C}$ where in the samples from $\mathrm{J}$ bag higher contents of all analyzed compounds have been reported. It was also noted that quantity of trigonelline and caffeine were also higher in jute bag than in $\mathrm{G}$ bag when samples were stored in the uncontrolled conditions. The same behavior of compounds was noticed in the RC samples.

\section{Sensory analysis}

One of the most important factors influencing consumer approval of a product are sensory features. The cupping form provides recording important flavour attributes for coffee: aroma, flavour, aftertaste, acidity, body, balance, uniformity, clean cup, sweetness and overall which are rated on a 16-point scale representing levels of quality in quarter point increments between numeric values from 6 to 9 , when 6.00-6.75 is good, 7.00-7.75 is very good, 8.00-8.75 is excellent and 9.00-9.75 is outstanding. The final score is calculated by summing the individual scores given for each attributes and additionally for clean cup, uniformity and sweetness. This score allows the coffee to qualify as specialty quality when is above 80 points [3].

After delivering coffee to Poland, the first sensory evaluation, so-called calibration, took place the day before the coffee samples were put into temperature chambers. Then all the attributes for the natural coffee brews: El Oregano (86.0 points of total score) and washed coffee brews: Finca La Maravilla (86.8 points of total score) were determined. The results confirmed the specialty quality of 
both coffees and were in accordance with Coradi, Borem, Saath, \& Marques [21] who noticed that washed coffee presents better quality when compared to the product in its natural form.

The first sensory evaluation of the coffees stored in the chambers was done after 3 months after placing both types of coffees at the indicated temperatures. After 12 months in chambers, the highest total score was achieved for RC samples from $-10^{\circ} \mathrm{C} \mathrm{GN}(81.1$ points), $10^{\circ} \mathrm{C}$ for both $\mathrm{GN}$ and $\mathrm{JN}$ bags (79.5 points), as also for $18^{\circ} \mathrm{C}$ and $\mathrm{UC}$ for $\mathrm{GN}$ (79.2 and 78.8 points respectively) (Table 3). While the lowest scores was recorded for the samples stored in UC in both jute bags: natural (76.5 points) and washed (76.8 points) as also for chamber $18^{\circ} \mathrm{C}$ for GW (76.7 points) and $20^{\circ} \mathrm{C}$ for $\mathrm{JN}$ (76.9 points) and GW (76.7 points). The highest diversity among the evaluated attributes occurred for acidity, where the difference between the best and worst results for all samples after 12 months storage was 0.94 points, followed closely by balance and overall, 0.87 points for both. The smallest differences were found within aroma- 0.56 points. However for all attributes fluctuations were at a similar level ranged from 2.3 to $3.0 \%$. After 12 months of coffee samples storage, a decrease ranged from $12.8 \%$ to $17.3 \%$ in the attributes of sensory analysis was noted in relation to calibration values. The largest difference between the attributes after 12 months compared to the fresh coffee occurred in aroma and was $17.3 \%$ of decline in relation to initial values (DRIV), followed closely by acidity (16.0 \% DRIV) and also in body and overall (15.8 and $15.9 \%$ DRIV respectively). The smallest decrease in sensory values was noted for the aftertaste (12.8\% DRIV) among all assessed attributes. Despite the highest total score for the RCs stored 12 months in chamber $-10^{\circ} \mathrm{C} \mathrm{GN}$, large fluctuations were recorded for the remaining types of packaging in this chamber $(\mathrm{RSD}=3.7 \%)$. Based on the results of the sensory analysis, it was found that the most flavour stable results were in chamber $10^{\circ} \mathrm{C}(\mathrm{RSD}=2.1 \%)$ and the highest values of assessed attributes were found in $\mathrm{JN}$ bag. Therefore, only the $10^{\circ} \mathrm{C}$ chambers and $\mathrm{JN}$ bags were considered in the further description. The lowest results were noticed for $20^{\circ} \mathrm{C}$ and UC.

The results of the sensory evaluation regarding the taste characteristics are graphically presented by means of radar charts (Fig. 3). They illustrate the changes that took place in RC from beginning of sensory evaluation in chambers (Fig. 3A) to 12 months (Fig. 3C) of storage in $10^{\circ} \mathrm{C}$ chamber taking into account the type of bag and way of coffee bean processing. It is easy to notice a decrease in the taste values of RC in all analyzed variants. The shape of the radar charts for all bags within chamber $10^{\circ} \mathrm{C}$ at the beginning of sensory evaluation in chambers were similar to the shape of the charts after the 12 month storage time. In both cases, all attributes remain on a similar level, ranged 7.3-7.8 points on beginning of sensory evaluation in chambers and 6.7-7.2 points after 12 months of storage. At the beginning of sensory evaluation in chambers, the highest attributes were felt for JW coffees and the body was characterized by the highest value, while after 12 months in $\mathrm{JN}$ the most taste values were felt.

Compared to other chamber temperatures, changes after 12 months in relation to calibration values to individual attributes were the smallest in $10^{\circ} \mathrm{C}$ (below 14.2\% DRIV) except for JW (17.2-18.1\% DRIV). We can also notice that the differences of sensory analysis for JN maintain the highest values for all attributes (9.3-11.6\% DRIV) except the slightly lower values for aroma (14.2\% DRIV) and body (12.4\% DRIV). The second pair of radar chart illustrates the changes within the jute natural bags on the beginning of sensory evaluation in chambers (Fig. 3B) and after 12 months storage (Fig. 3D), showing all tested temperatures. Comparing the shapes of the radar charts in all JN bags, we can observe that they differ significantly from each other. At the beginning of sensory evaluation in chambers, all attributes remained at a similar level (7.0-7.7 points) and the flavour was the most noticeable in chambers $-10,5$ and $10^{\circ} \mathrm{C}$, aroma in $18^{\circ} \mathrm{C}$, acidity in $20^{\circ} \mathrm{C}$ and UC. The highest total score of quality classification was achieved for $10^{\circ} \mathrm{C}$ chamber (82.4 points) while the lowest for $18^{\circ} \mathrm{C}(79.9$ points). While after 12 months of storage, acidity and overall play the main role in the assessment of taste and attributes ranged from 6.6 to 7.2 points. The highest total score of quality classification was achieved for $10^{\circ} \mathrm{C}$ chamber (79.5 points) while the lowest for UC (76.5 points). Here, the greatest decrease in relation to initial is noticeable for chambers: $20^{\circ} \mathrm{C}$ (13.7-17.8\% DRIV), UC (13.7-18.5\% DRIV) and - $10^{\circ} \mathrm{C}$ (13.7-16.7\% DRIV). While the results for RC samples stored in the $\mathrm{JN}$ bag at $10^{\circ} \mathrm{C}$ showed the smallest decrease among all assessed attributes (9.3-14.2\% DRIV).

\section{Statistical analysis}

\section{Correlations}

Correlation matrix was used to find significant correlations between considered variables (Table 4). This compilation allowed to observe that the increase in storage temperature causes a loss of flavour and aroma of coffee brews at the same time causing a growth of the 4-CQA content. In addition, jute bag affected the body attribute. Washed post-harvest process showed the relationship 
with the content of CQAs while natural process with the other parameters, furthermore trigonelline more strongly. All CQAs strongly positively correlate with each other, weaker with caffeine and 4-CQA further contributes to the aroma. The caffeine content corresponded strongly to the trigonelline and also affected on aftertaste, acidity and overall, while trigonelline correlates with all attributes except body.

\section{Differentiation of green and roasted coffee brews after 12 months of storage, taking into account chemical discriminants}

To illustrate the relationship between the concentration of the compounds in the GCs and RCs and different storage conditions, the chemometric analysis such as: PCA, CA was applied. On the basis of the presented tree diagram (Fig. 4A.), it can be concluded that taking into account the Sneath criterion, among the analyzed samples of GCs and RCs, two groups showing mutual similarity can be clearly distinguished. The first group includes RC (purple and blue marking), while the second GC brews (green marking). Inside the RC group the distinction between washed (purple) and natural (blue) coffees is also observed. The cluster analysis technique proved to be helpful in the identification of coffee samples in terms of both the type of grain (CG, RC) and the method of its postharvest treatment (N.W).

Next, a principal component analysis (PCA) was performed to explain the differences between the GC and RC coffees in terms of storage conditions. These results are shown in the system of the two first principal components: PC1 and PC2. The analysis of factor loadings matrix of variables in the factor space shows that the first component consists of highly correlated $(>0.96)$ variables such as positively correlated CQAs and negatively caffeine and trigonelline (Table 5A). Two main factors with eigenvalues higher than one explain over $98.5 \%$ of the data variance while the first distinguished factor (PC1) explains nearly $96.5 \%$ of the data variance, and its eigenvalue of 4.8 indicates that it contains information originally explained by nearly 5 variables used to describe the research object (Fig. 4B).

The factorial arrangement of coffee sample objects allowed for the identification of 3 groups: a. blue: RCs in GN and JN bags, $b$. purple: RCs in GW and JW bags, c. black GCs in JN and GN bags and also and green: GCs in JW and GW bags. The location of the group of GC extracts from all types of bags (ellipse c) indicates a greater importance of the discriminants related to the presence of CQAs, in relation to the both RC extract groups $a$ and $b$. While the position of the group of RC extracts from JN and GN bags (ellipse a) shows a greater importance of caffeine and trigonelline - related factors compare to the rest groups. In the case of both RC and GC samples, the determined components have values at a similar level of differentiation along the first principal component. PCA analysis showed that in the chemical perception of GC and RC all the tested compounds have different significance. The high content of CQAs in coffee beverages is more important in the case of GC brews of all bag types and allow to visualize them as a group along positive PC1 values. In turn, high levels of caffeine and trigonelline group RC brews along negative values.

\section{Differentiation of roasted coffee brews after 12 months of storage, taking into account chemical and sensory discriminants.}

The analysis of factor loadings matrix of variables in the fac tor space shows that the first component consists of highly negative correlated (>0.94) all sensory attributes as also a little weaker trigonelline while 4-CQA was positively correlated. The second principal component was caffeine (in plus) and 3-CQA (in minus) (Table 5B). Figure 5 represents the CA and PCA of chemical and sensorial characteristics of RC grains after 12 months of storage in different conditions. The presented dendrogram (Fig. 5A) graphically shows the partition of the analyzed RC in terms of its post-harvest treatment method into two groups: coming from natural and washed process (Sneath criterion).

A similar tendency was repeated in the PCA (Fig. 5B) taking into consideration data obtained for CQAs, caffeine, trigonelline and sensory characteristics. PCA analysis allowed to visually divide the analyzed coffee samples into two sectors: natural- with negative PC1 and positive PC2 values as also washed- with positive PC1 and negative PC2 values. The factorial arrangement of coffee sample objects allowed for the identification of 4 groups: a. light green: RC derived from natural process and stored in $\mathrm{G}$ and $\mathrm{J}$ in 5 and $10^{\circ} \mathrm{C}$ chamber, b. dark green: RC derived from natural process and stored in $\mathrm{G}$ and $\mathrm{J}$ in $-10,18,20^{\circ} \mathrm{C}$ and $\mathrm{UC}$ chamber, $\mathrm{C}$. dark blue: RC derived from washed process and stored in $\mathrm{G}$ and $\mathrm{J}$ in $-10,18,20^{\circ} \mathrm{C}$ and $\mathrm{UC}$ chamber, d. light blue: RC derived from washed process and stored in $\mathrm{G}$ and $\mathrm{J}$ in 5 and $10^{\circ} \mathrm{C}$ chamber. Two main factors with eigenvalues higher than one explain over $94.7 \%$ of the data variance. 
The first distinguished factor (PC1) explains nearly $71.9 \%$ of the data variance, and its eigenvalue of 8.6 indicates that it contains information originally explained by nearly 9 variables used to describe the research object. The second distinguished factor (PC2) explains nearly $22.8 \%$ and translates the information of the other three variables. The location of the RC extracts group from JN and $\mathrm{GN}$ in 5 and $10^{\circ} \mathrm{C}$ (ellipse a) indicates a greater importance of the discriminants related to the high presence of trigonelline and all sensory attributes which translates into a high total score value. In contrast to light blue group (ellipse d) where presence of 4-CQA is more important while the caffeine and 3-CQA content within both groups fluctuate at similar levels. In the case of both washed and natural RCs from $b$ and c ellipse, the determined components have values at a similar level of differentiation along the first principal component. While in b group infusions with high caffeine importance and lower 3-CQA can be distinguished in opposite to c group.

In this work it has been shown that there is a huge effect of packaging materials, temperature and time of storage on CQAs, caffeine and trigonelline as well. The results show, that for both, natural and washed coffee samples, GrainPro bag can preserve CQAs, caffeine and trigonelline in GC beans better than jute bag during storage time. The exception is chamber $10^{\circ} \mathrm{C}$ where in the samples from jute bag higher contents of all analyzed compounds have been reported. In sensory analysis, the highest grade in terms of general quality was the coffee stored in the $-10^{\circ} \mathrm{C}$ chamber in $\mathrm{GN}$ bag. However, large fluctuations for the remaining types of packaging in this chamber and lower profitability of keeping such a low temperature in warehouses influenced the selection $10^{\circ} \mathrm{C}$ chamber and JN bags where quality was comparably high. In this case, the decrease in taste values in relation to fresh coffee (calibration value) was only $7.6 \%$ and the most noticeable taste was acidity as also overall and the total result in the quality classification was 79.5 points. While the lowest results were noticed for $20^{\circ} \mathrm{C}$ and UC. A score $>79$ can be defined to be almost a specialty level. Certainly, these are Premium quality coffees, which constitute a relatively low percentage of the total coffee production in the world.

The PCA analysis showed that in the perception of the chemical and sensory properties of RCs, all tested compounds have different meanings, however, it allows them to be grouped. In order to optimize GC storage conditions, it would be advisable to continue the research in the future by narrowing the temperature range to 7,10 and $13^{\circ} \mathrm{C}$, as well as checking the vacuum packaging.

\section{Declarations}

\section{Author contributions statement}

M.Z., N.S., K.B., R.K. conceived the experiments, M.Z., N.S., K.B., A.J., D.A., R.M. conducted the experiments, M.Z., N.S., K.B., R.K., Ł.B. analysed the results. All authors reviewed the manuscript.

\section{Additional information}

The authors declare that they have no known competing financial interests or personal relationships that could have appeared to influence the work reported in this paper.

\section{References}

1. Annual review 2019 addressing the coffee price crisis.International Coffee Organization(2019).

2. Fischer, E. F., Victor, B., Robinson, D., Farah, A. \& Martin, P. R. CHAPTER 1. Coffee consumption and health impacts: A

3. brief history of changing conceptions In. Coffee, 1-19, DOI: 10.1039/9781788015028-00001 (Royal Society of Chemistry, 2019).

4. Scaa protocols | cupping specialty coffee.,Specialty Coffee Association of America(2015).

5. Bladyka, E. Scaa member-driven research. coffee staling report., Specialty Coffee Association of America(2013).

6. Yeretzian, C., Blank, I. \& Wyser, Y. Protecting the flavors-freshness as a key to quality. In The Craft and Science of Coffee, 329353, DOI: 10.1016/b978-0-12-803520-7.00014-1 (Elsevier, 2017).

7. Jaimes, E. M. S., Torres, I. B. \& Villarreal, H. H. P. Sensory evaluation of commercial coffee brands in Colombia. Int. J. Bus. Syst. Res. 9, 195, DOI: 10.1504/ijbsr.2015.071831 (2015). 
8. Barahona, I., Jaimes, E. M. S. \& Yang, J. B. Sensory attributes of coffee beverages and their relation to price and package information: A case study of colombian customers' preferences. Food Sci. \& Nutr. 8, 1173-1186, DOI: 10.1002/fsn3.1404 (2020).

9. Bidel, S. \& Tuomilehto, J. \& and. The emerging health benefits of coffee with an emphasis on type 2 diabetes and cardiovascular disease. Eur. Endocrinol. 9, 99, DOI: 10.17925/ee.2013.09.02.99 (2010).

10. Ludwig, I. A., Clifford, M. N., Lean, M. E. J., Ashihara, H. \& Crozier A. Coffee: biochemistry and potential impact on

11. health. Food Funct. 5, 1695-1717, DOI: 10.1039/c4fo00042k (2014).

12. Samoggia, A. \& Riedel, B. Consumers' perceptions of coffee health benefits and motives for coffee consumption and purchasing. Nutrients 11, 653, DOI: 10.3390/nu11030653 (2019).

13. Grujic-Letic, N. et al. Determination of 5-caffeoylquinic acid (5-CQA) as one of the major classes of chlorogenic acid in commercial tea and coffee samples. Vojnosanitetski pregled 72, 1018-1023, DOI: 10.2298/vsp130915096g (2015).

14. Janissen, B. \& Huynh, T. Chemical composition and value-adding applications of coffee industry by-products: A review.

15. Resour \& Conserv Recycl. 128, 110-117 https://doi.org/10.1016/j.resconrec.2017.10.001 (2018).

16. Allred, K. F., Yackley, K. M., Vanamala, J. \& Allred, C. D. Trigonelline is a novel phytoestrogen in coffee beans. The J. Nutr. 139, 1833-1838, DOI: 10.3945/jn.109.108001 (2009).

17. Godos, J. et al. Coffee components and cardiovascular risk: beneficial and detrimental effects. Int. J. Food Sci. Nutr. 65,

18. -936, DOI: 10.3109/09637486.2014.940287 (2014).

19. Hecimovi `c,', I., Belšcak -Cvitanovic,', A., Horžic,', D. \& Komes, D. Comparative study of polyphenols and caffeine in different coffee varieties affected by the degree of roasting. Food Chem. 129, 991-1000, DOI: 10.1016/j.foodchem.2011.05.059 (2011).

20. Dybkowska, E. et al. Assessing polyphenols content and antioxidant activity in coffee beans according to origin and the degree of roasting(2017).

21. Król, K., Gantner, M., Tatarak, A. \& Hallmann, E. The content of polyphenols in coffee beans as roasting, origin and storage effect. Eur. Food Res. Technol. 246, 33-39, DOI: 10.1007/s00217-019-03388-9 (2019).

22. da Rosa, J. S. et al. Mass spectrometry screening of arabica coffee roasting: A non-target and non-volatile approach by

23. EASI-MS and ESI-MS. Food Res. Int. 89, 967-975 https://doi.org/10.1016/j.foodres.2016.03.021 (2016).

24. Barbosa, S. G., dos Santos Scholz, M., Kitzberger, M. B., de Toledo Benassi, M. \& C. S. G. \& Correlation between the composition of green arabica coffee beans and the sensory quality of coffee brews. Food Chem. 292, 275-280 https://doi.org/10.1016/j.foodchem.2019.04.072 (2019).

25. Meinhart, A. D. et al. Chlorogenic acid isomer contents in 100 plants commercialized in brazil. Food Res. Int. 99, 522-530, DOI: 10.1016/j.foodres.2017.06.017 (2017).

26. Coradi, P., Borém, F. M., Saath, R. \& Marques, E. R. Effect of drying and storage conditions on the quality of natural and washed coffee, DOI: 10.13140/RG.2.1.4880.7523 (2015).

27. Scheidig, C., Czerny, M. \& Schieberle, P. Changes in key odorants of raw coffee beans during storage under defined conditions. J. Agric. Food Chem. 55, 5768-5775, DOI: 10.1021/jf070488o (2007).

28. Selmar, D., Bytof, G. \& Knopp, S. E. The storage of green coffee (coffea arabica): Decrease of viability and changes of potential aroma precursors. Annals Bot. 101, 31-38, DOI: 10.1093/aob/mcm277 (2007).

29. Tripetch, P. \& Borompichaichartkul, C. Effect of packaging materials and storage time on changes of colour, phenolic content, chlorogenic acid and antioxidant activity in arabica green coffee beans (coffea arabica I. cv. catimor). J. Stored Prod. Res. 84, 101510, DOI: 10.1016/j.jspr.2019.101510 (2019).

30. Ross, C. F., Pecka, K. \& Weller, K. Effect of storage conditions on the sensory quality of ground arabica coffee. J. Food Qual. 29, 596-606, DOI: 10.1111/j.1745-4557.2006.00093.x (2006).

31. Voilley, A., Sauvageot, F., Simatos, D. \& Wojcik, G. influence of some processing conditions on the quality of coffee brew. J. Food Process. Preserv. 5, 135-143, DOI: 10.1111/j.1745-4549.1981.tb00629.x (1981).

32. Jeszka-Skowron, M., Sentkowska, A., Pyrzynska,', K. \& Peña, M. P. D. Chlorogenic acids, caffeine content and antioxidant properties of green coffee extracts: influence of green coffee bean preparation. Eur. Food Res. Technol. 242. 1403-1409 https://doi.org/10.1007/s00217-016-2643-y (2016).

Page 9/19 
33. Ludwig, I. et al. Variations in caffeine and chlorogenic acid contents of coffees: what are we drinking? food funct, DOI: 10.1039/c4fo00290c (2014 Aug).

34. Rodrigues, N. P. \& Bragagnolo, N. Identification and quantification of bioactive compounds in coffee brews by HPLC-DADMSn. J. Food Compos. Analysis 32, 105-115, DOI: 10.1016/j.jfca.2013.09.002 (2013).

35. Wei, F. \& Tanokura, M. Chemical changes in the components of coffee beans during roasting. In V. R. Preedy (Ed.)Coffee in Health and Disease Prevention (Elsevier, 2015), https://doi.org/10.1016/C2012-0-06959-1

36. Budryn, G. et al. Effect of different extraction methods on the recovery of chlorogenic acids, caffeine and maillard reaction products in coffee beans. Eur. Food Res. Technol. 228, 913-922, DOI: 10.1007/s00217-008-1004-x (2009).

37. Casal, S., Oliveira, M. B. \& Ferreira, M. A. HPLC/diode-array applied to the thermal degradation of trigonelline, nicotinic acid and caffeine in coffee. Food Chem. 68. 481-485 https://doi.org/10.1016/s0308-8146(99)00228-9 (2000).

\section{Tables}

Table 1. The level of identified chemical compounds $(\mathrm{mg} / 100 \mathrm{~g})$ in green and roasted coffee. The values represent average \pm standard deviation, $\mathrm{n}=6$. 


\begin{tabular}{|c|c|c|c|c|c|c|c|c|c|c|c|}
\hline \multirow{3}{*}{$\begin{array}{l}\text { Temp. } \\
{\left[{ }^{\circ} \mathrm{C}\right]}\end{array}$} & \multirow{3}{*}{$\begin{array}{l}\text { Type of } \\
\text { packaging* }\end{array}$} & \multicolumn{10}{|c|}{$[\mathrm{mg} / 100 \mathrm{~g}], \mathrm{n}=6$} \\
\hline & & \multicolumn{5}{|c|}{ Green coffee (GC) } & \multicolumn{5}{|c|}{ Roasted coffee (RC) } \\
\hline & & 3-CQA* & $\begin{array}{l}\text { 5- } \\
\mathrm{CQA}^{*}\end{array}$ & $\begin{array}{l}\text { 4- } \\
\mathrm{CQA}\end{array}$ & Caffeine & $\begin{array}{l}\text { Trigone- } \\
\text { Iline }\end{array}$ & $\begin{array}{l}\text { 3- } \\
\mathrm{CQA}^{*}\end{array}$ & $\begin{array}{l}\text { 5- } \\
\mathrm{CQA}^{*}\end{array}$ & $\begin{array}{l}4- \\
\mathrm{CQA}^{*}\end{array}$ & $\begin{array}{l}\text { Caffe- } \\
\text { ine }\end{array}$ & $\begin{array}{l}\text { Trigone- } \\
\text { lline }\end{array}$ \\
\hline \multirow[t]{4}{*}{-10} & GN & $3955 \pm 85$ & $\begin{array}{l}356 \\
\pm 11\end{array}$ & $\begin{array}{l}508 \\
\pm 15\end{array}$ & $\begin{array}{l}1148 \\
\pm 76\end{array}$ & $\begin{array}{l}1273 \\
\pm 72\end{array}$ & $\begin{array}{l}1567 \\
\pm 25\end{array}$ & $\begin{array}{l}553 \\
\pm 16\end{array}$ & $\begin{array}{l}562 \\
\pm 11\end{array}$ & $\begin{array}{l}1010 \\
\pm 17\end{array}$ & $\begin{array}{l}1232 \\
\pm 29\end{array}$ \\
\hline & $\mathrm{JN}$ & $3744 \pm 157$ & $\begin{array}{l}327 \\
\pm 16\end{array}$ & $\begin{array}{l}474 \\
\pm 26\end{array}$ & $\begin{array}{l}1019 \\
\pm 50\end{array}$ & $\begin{array}{l}1169 \\
\pm 48\end{array}$ & $\begin{array}{l}1294 \\
\pm 88\end{array}$ & $\begin{array}{l}448 \\
\pm 56\end{array}$ & $\begin{array}{l}487 \\
\pm 38\end{array}$ & $\begin{array}{l}890 \\
\pm 67\end{array}$ & $\begin{array}{l}1092 \\
\pm 72\end{array}$ \\
\hline & GW & $3231 \pm 67$ & $\begin{array}{l}254 \\
\pm 7\end{array}$ & $\begin{array}{l}381 \\
\pm 10\end{array}$ & $836 \pm 26$ & $\begin{array}{l}963 \\
\pm 18\end{array}$ & $\begin{array}{l}1388 \\
\pm 58\end{array}$ & $\begin{array}{l}458 \\
\pm 22\end{array}$ & $\begin{array}{l}543 \\
\pm 26\end{array}$ & $\begin{array}{l}836 \\
\pm 38\end{array}$ & $\begin{array}{r}973 \\
\pm 34\end{array}$ \\
\hline & JW & $3305 \pm 28$ & $\begin{array}{l}259 \\
\pm 3\end{array}$ & $\begin{array}{l}388 \\
\pm 7\end{array}$ & $835 \pm 11$ & $961 \pm 8$ & $\begin{array}{l}1335 \\
\pm 19\end{array}$ & $\begin{array}{l}429 \\
\pm 9\end{array}$ & $\begin{array}{l}518 \\
\pm 8\end{array}$ & $\begin{array}{l}871 \\
\pm 12\end{array}$ & $\begin{array}{l}979 \\
\pm 10\end{array}$ \\
\hline \multirow[t]{4}{*}{5} & GN & $3148 \pm 38$ & $\begin{array}{l}283 \\
\pm 6\end{array}$ & $\begin{array}{l}400 \\
\pm 7\end{array}$ & $953 \pm 14$ & $\begin{array}{l}1135 \\
\pm 20\end{array}$ & $\begin{array}{l}1343 \\
\pm 7\end{array}$ & $\begin{array}{l}426 \\
\pm 5\end{array}$ & $\begin{array}{l}515 \\
\pm 8\end{array}$ & $\begin{array}{l}980 \\
\pm 11\end{array}$ & $\begin{array}{l}1170 \\
\pm 8\end{array}$ \\
\hline & JN & $3170 \pm 29$ & $\begin{array}{l}281 \\
\pm 4\end{array}$ & $\begin{array}{l}396 \\
\pm 7\end{array}$ & $988 \pm 16$ & $\begin{array}{l}1156 \\
\pm 21\end{array}$ & $\begin{array}{l}1314 \\
\pm 12\end{array}$ & $\begin{array}{l}410 \\
\pm 6\end{array}$ & $\begin{array}{l}505 \\
\pm 8\end{array}$ & $\begin{array}{l}985 \\
\pm 12\end{array}$ & $\begin{array}{l}1170 \\
\pm 9\end{array}$ \\
\hline & GW & $2681 \pm 81$ & $\begin{array}{l}206 \\
\pm 4\end{array}$ & $\begin{array}{l}302 \\
\pm 7\end{array}$ & $868 \pm 14$ & $984 \pm 9$ & $\begin{array}{l}1790 \\
\pm 110\end{array}$ & $\begin{array}{l}594 \\
\pm 37\end{array}$ & $\begin{array}{l}734 \\
\pm 52\end{array}$ & $\begin{array}{l}1123 \\
\pm 75\end{array}$ & $\begin{array}{l}1215 \\
\pm 86\end{array}$ \\
\hline & JW & $2427 \pm 133$ & $\begin{array}{l}189 \\
\pm 10\end{array}$ & $\begin{array}{l}278 \\
\pm 16\end{array}$ & $830 \pm 30$ & $\begin{array}{l}980 \\
\pm 25\end{array}$ & $\begin{array}{l}1669 \\
\pm 71\end{array}$ & $\begin{array}{l}543 \\
\pm 34\end{array}$ & $\begin{array}{l}673 \\
\pm 29\end{array}$ & $\begin{array}{l}1033 \\
\pm 40\end{array}$ & $\begin{array}{l}1133 \\
\pm 36\end{array}$ \\
\hline \multirow[t]{4}{*}{10} & GN & $2770 \pm 36$ & $\begin{array}{l}250 \\
\pm 2\end{array}$ & $\begin{array}{l}350 \\
\pm 7\end{array}$ & $949 \pm 13$ & $\begin{array}{l}1159 \\
\pm 15\end{array}$ & $\begin{array}{l}1405 \\
\pm 47\end{array}$ & $\begin{array}{l}440 \\
\pm 22\end{array}$ & $\begin{array}{l}540 \\
\pm 22\end{array}$ & $\begin{array}{l}1093 \\
\pm 35\end{array}$ & $\begin{array}{l}1243 \\
\pm 60\end{array}$ \\
\hline & JN & $4279 \pm 315$ & $\begin{array}{l}396 \\
\pm 31\end{array}$ & $\begin{array}{l}567 \\
\pm 34\end{array}$ & $\begin{array}{l}1162 \\
\pm 86\end{array}$ & $\begin{array}{l}1289 \\
\pm 85\end{array}$ & $\begin{array}{l}1574 \\
\pm 29\end{array}$ & $\begin{array}{l}500 \\
\pm 16\end{array}$ & $\begin{array}{l}624 \\
\pm 13\end{array}$ & $\begin{array}{l}1157 \\
\pm 19\end{array}$ & $\begin{array}{l}1325 \\
\pm 25\end{array}$ \\
\hline & GW & $4116 \pm 125$ & $\begin{array}{l}334 \\
\pm 10\end{array}$ & $\begin{array}{l}507 \\
\pm 17\end{array}$ & $920 \pm 25$ & $\begin{array}{l}979 \\
\pm 27\end{array}$ & $\begin{array}{l}1614 \\
\pm 28\end{array}$ & $\begin{array}{l}526 \\
\pm 13\end{array}$ & $\begin{array}{l}644 \\
\pm 13\end{array}$ & $\begin{array}{l}1025 \\
\pm 18\end{array}$ & $\begin{array}{l}1121 \\
\pm 14\end{array}$ \\
\hline & JW & $3860 \pm 78$ & $\begin{array}{l}312 \\
\pm 9\end{array}$ & $\begin{array}{l}472 \\
\pm 12\end{array}$ & $871 \pm 27$ & $\begin{array}{l}949 \\
\pm 11\end{array}$ & $\begin{array}{l}1649 \\
\pm 7\end{array}$ & $\begin{array}{l}540 \\
\pm 9\end{array}$ & $\begin{array}{l}665 \\
\pm 5\end{array}$ & $\begin{array}{l}1037 \\
\pm 12\end{array}$ & $\begin{array}{l}1121 \\
\pm 7\end{array}$ \\
\hline \multirow[t]{4}{*}{18} & GN & $3595 \pm 46$ & $\begin{array}{l}323 \\
\pm 5\end{array}$ & $\begin{array}{l}469 \\
\pm 9\end{array}$ & $944 \pm 19$ & $\begin{array}{l}1103 \\
\pm 9\end{array}$ & $\begin{array}{l}1544 \\
\pm 26\end{array}$ & $\begin{array}{l}489 \\
\pm 11\end{array}$ & $\begin{array}{l}607 \\
\pm 11\end{array}$ & $\begin{array}{l}1178 \\
\pm 19\end{array}$ & $\begin{array}{l}1361 \\
\pm 20\end{array}$ \\
\hline & JN & $3524 \pm 38$ & $\begin{array}{l}327 \\
\pm 4\end{array}$ & $\begin{array}{l}465 \\
\pm 11\end{array}$ & $966 \pm 3$ & $\begin{array}{l}1116 \\
\pm 7\end{array}$ & $\begin{array}{l}1612 \\
\pm 11\end{array}$ & $\begin{array}{l}516 \\
\pm 8\end{array}$ & $\begin{array}{l}638 \\
\pm 6\end{array}$ & $\begin{array}{l}1149 \\
\pm 10\end{array}$ & $\begin{array}{l}1342 \\
\pm 9\end{array}$ \\
\hline & GW & $3589 \pm 63$ & $\begin{array}{l}295 \\
\pm 8\end{array}$ & $\begin{array}{l}437 \\
\pm 13\end{array}$ & $848 \pm 15$ & $969 \pm 7$ & $\begin{array}{l}1427 \\
\pm 8\end{array}$ & $\begin{array}{l}459 \\
\pm 6\end{array}$ & $\begin{array}{l}556 \\
\pm 3\end{array}$ & $\begin{array}{l}920 \\
\pm 7\end{array}$ & $\begin{array}{l}1029 \\
\pm 3\end{array}$ \\
\hline & JW & $3597 \pm 84$ & $\begin{array}{l}294 \\
\pm 7\end{array}$ & $\begin{array}{l}438 \\
\pm 12\end{array}$ & $876 \pm 8$ & $981 \pm 2$ & $\begin{array}{l}1481 \\
\pm 18\end{array}$ & $\begin{array}{l}464 \\
\pm 5\end{array}$ & $\begin{array}{l}591 \\
\pm 13\end{array}$ & $\begin{array}{r}919 \\
\pm 13\end{array}$ & $\begin{array}{l}1033 \\
\pm 2\end{array}$ \\
\hline \multirow[t]{4}{*}{20} & GN & $3425 \pm 65$ & $\begin{array}{l}312 \\
\pm 5\end{array}$ & $\begin{array}{l}439 \\
\pm 8\end{array}$ & $982 \pm 29$ & $\begin{array}{l}1172 \\
\pm 12\end{array}$ & $\begin{array}{l}1437 \\
\pm 17\end{array}$ & $\begin{array}{l}447 \\
\pm 8\end{array}$ & $\begin{array}{l}584 \\
\pm 28\end{array}$ & $\begin{array}{l}990 \\
\pm 18\end{array}$ & $\begin{array}{l}1181 \\
\pm 17\end{array}$ \\
\hline & JN & $3290 \pm 46$ & $\begin{array}{l}310 \\
\pm 3\end{array}$ & $\begin{array}{l}430 \\
\pm 4\end{array}$ & $943 \pm 25$ & $\begin{array}{l}1141 \\
\pm 7\end{array}$ & $\begin{array}{l}1324 \\
\pm 71\end{array}$ & $\begin{array}{l}407 \\
\pm 25\end{array}$ & $\begin{array}{l}540 \\
\pm 39\end{array}$ & $\begin{array}{l}948 \\
\pm 55\end{array}$ & $\begin{array}{l}1121 \\
\pm 48\end{array}$ \\
\hline & GW & $3093 \pm 50$ & $\begin{array}{l}254 \\
\pm 5\end{array}$ & $\begin{array}{l}368 \\
\pm 8\end{array}$ & $879 \pm 16$ & $\begin{array}{l}1016 \\
\pm 12\end{array}$ & $\begin{array}{l}1607 \\
\pm 22\end{array}$ & $\begin{array}{l}516 \\
\pm 8\end{array}$ & $\begin{array}{l}650 \\
\pm 12\end{array}$ & $\begin{array}{l}900 \\
\pm 14\end{array}$ & $\begin{array}{l}1041 \\
\pm 8\end{array}$ \\
\hline & JW & $3970 \pm 150$ & $\begin{array}{l}331 \\
\pm 10\end{array}$ & $\begin{array}{l}508 \\
\pm 19\end{array}$ & $856 \pm 31$ & $\begin{array}{l}911 \\
\pm 23\end{array}$ & $\begin{array}{l}1610 \\
\pm 36\end{array}$ & $\begin{array}{l}516 \\
\pm 13\end{array}$ & $\begin{array}{l}654 \\
\pm 19\end{array}$ & $\begin{array}{l}943 \\
\pm 25\end{array}$ & $\begin{array}{l}1080 \\
\pm 20\end{array}$ \\
\hline \multirow{2}{*}{$\begin{array}{l}\text { Uncontrolled } \\
\text { conditions }\end{array}$} & GN & $3686 \pm 100$ & $\begin{array}{l}312 \\
\pm 6\end{array}$ & $\begin{array}{l}498 \\
\pm 50\end{array}$ & $814 \pm 19$ & $903 \pm 8$ & $\begin{array}{l}1561 \\
\pm 25\end{array}$ & $\begin{array}{l}491 \\
\pm 8\end{array}$ & $\begin{array}{l}654 \\
\pm 42\end{array}$ & $\begin{array}{l}1086 \\
\pm 20\end{array}$ & $\begin{array}{l}1314 \\
\pm 26\end{array}$ \\
\hline & $\mathrm{JN}$ & $3566 \pm 51$ & $\begin{array}{l}331 \\
\pm 2\end{array}$ & $\begin{array}{l}472 \\
\pm 5\end{array}$ & $956 \pm 33$ & $\begin{array}{l}1119 \\
\pm 16\end{array}$ & $\begin{array}{l}1468 \\
\pm 67\end{array}$ & $\begin{array}{l}456 \\
\pm 23\end{array}$ & $\begin{array}{l}625 \\
\pm 41\end{array}$ & $\begin{array}{l}1179 \\
\pm 61\end{array}$ & $\begin{array}{l}1333 \\
\pm 68\end{array}$ \\
\hline
\end{tabular}




\begin{tabular}{lllllllllll|} 
GW & $3568 \pm 46$ & 296 & 445 & $824 \pm 9$ & $935 \pm 5$ & 1613 & 517 & 651 & 972 & 1117 \\
& & \pm 5 & \pm 11 & & & \pm 20 & \pm 6 & \pm 8 & \pm 12 & \pm 2 \\
\hline \multirow{3}{*}{$\mathrm{JW}$} & $3601 \pm 56$ & 296 & 456 & $864 \pm 21$ & 1008 & 1547 & 486 & 617 & 993 & 1114 \\
& & \pm 18 & \pm 50 & & \pm 6 & \pm 22 & \pm 8 & \pm 10 & \pm 13 & \pm 11 \\
\hline
\end{tabular}

*3-CQA-3-0-caffeoylquinic acid, 4-CQA-4-0-caffeoylquinic acid, 5-CQA- 5-0-caffeoylquinic acid, GN- Grain-Pro natural, JN- Juta natural, GW- Grain-Pro washed, JW- Juta washed

Table 2. Validation parameters and chromatographic data of the HPLC-DAD method.

\begin{tabular}{|c|c|c|c|c|c|c|c|c|c|}
\hline Compound & $\begin{array}{l}\text { Equation of } \\
\text { analyticalcurve }\end{array}$ & $\lambda^{*}$ & LOD* & LOQ* & $\begin{array}{l}\text { Linear } \\
\text { range }\end{array}$ & $R^{*}$ & $\begin{array}{l}\text { RSD* } \\
\%\end{array}$ & $\begin{array}{l}\text { Accuracy } \\
{[\%]}\end{array}$ & $\begin{array}{l}\mathrm{tR}^{\star} \\
{[\mathrm{min}]}\end{array}$ \\
\hline & & [nm] & {$[\mathrm{mg} / 100 \mathrm{~g}]$} & {$[\mathrm{mg} / 100 \mathrm{~g}]$} & $\begin{array}{l}\text { [mg/100 } \\
\mathrm{g}]\end{array}$ & & & & \\
\hline $5-\mathrm{CQA}^{*}$ & $y=0.9342 x-0.0292$ & 325 & 10 & 34 & $1-6$ & 0.999 & 2.3 & 103.4 & 3.6 \\
\hline 3-CQA* & $y=0.8928 x-2.6578$ & 325 & 64 & 213 & $15-60$ & 0.998 & 2.9 & 104.7 & 7.9 \\
\hline 4-CQA* & & & & & & & & & 9.9 \\
\hline Trigonelline & $y=0.3824 x-1.8094$ & 272 & 109 & 363 & $5 .-30$ & 0,992 & 2.8 & 97.6 & 1.0 \\
\hline Caffeine & $y=1.1672 x-0.2488$ & 272 & 12 & 39 & $3-30$ & 0.997 & 1.9 & 88.2 & 8.7 \\
\hline
\end{tabular}

${ }^{*} \boldsymbol{\lambda}$ - wavelength, LOD- Limit of detection, LOQ- Limit of quantification, R-Correlation coefficient, RSD- Relative standard deviation, $\mathbf{t}_{\mathbf{R}^{-}}$ retention time, 3-CQA-3-0-caffeoylquinic acid, 4-CQA-4-0-caffeoylquinic acid, 5-CQA-5-0-caffeoylquinic acid.

Table 3. The level of identified sensor attributes (points) in roasted coffee. The values represent average \pm standard deviation, $\mathrm{n}=10 .{ }^{*} \mathrm{GN}$ - Grain-Pro natural, JN- Juta natural, GW- GrainPro washed, JW- Juta washed 


\begin{tabular}{|c|c|c|c|c|c|c|c|c|c|}
\hline Temperature & Type of & [points], & & & & & & & \\
\hline & & Roastec & ffee (RC) & & & & & & \\
\hline & & Aroma & Flavour & Aftertaste & Acidity & Body & Balance & Overall & $\begin{array}{l}\text { Total } \\
\text { score }\end{array}$ \\
\hline-10 & GN & $\begin{array}{l}7.19 \\
\pm 0.18\end{array}$ & $\begin{array}{l}7.31 \\
\pm 0.09\end{array}$ & $\begin{array}{l}7.13 \\
\pm 0.09\end{array}$ & $\begin{array}{l}7.47 \\
\pm 0.04\end{array}$ & $\begin{array}{l}7.31 \\
\pm 0.00\end{array}$ & $\begin{array}{l}7.34 \\
\pm 0.04\end{array}$ & $\begin{array}{l}7.31 \\
\pm 0.09\end{array}$ & $\begin{array}{l}81.06 \\
\pm 0.09\end{array}$ \\
\hline & $\mathrm{JN}$ & $\begin{array}{l}6.81 \\
\pm 0.09\end{array}$ & $\begin{array}{l}6.84 \\
\pm 0.31\end{array}$ & $\begin{array}{l}6.69 \\
\pm 0.27\end{array}$ & $\begin{array}{l}6.78 \\
\pm 0.31\end{array}$ & $\begin{array}{l}6.81 \\
\pm 0.35\end{array}$ & $\begin{array}{l}6.72 \\
\pm 0.31\end{array}$ & $\begin{array}{l}6.72 \\
\pm 0.22\end{array}$ & $\begin{array}{l}77.38 \\
\pm 1.86\end{array}$ \\
\hline & GW & $\begin{array}{l}6.94 \\
\pm 0.00\end{array}$ & $\begin{array}{l}6.94 \\
\pm 0.09\end{array}$ & $\begin{array}{l}6.72 \\
\pm 0.13\end{array}$ & $\begin{array}{l}6.69 \\
\pm 0.00\end{array}$ & $\begin{array}{l}6.78 \\
\pm 0.04\end{array}$ & $\begin{array}{l}6.75 \\
\pm 0.00\end{array}$ & $\begin{array}{l}6.75 \\
\pm 0.09\end{array}$ & $\begin{array}{l}77.56 \\
\pm 0.35\end{array}$ \\
\hline & JW & $\begin{array}{l}6.91 \\
\pm 0.31\end{array}$ & $\begin{array}{l}6.75 \\
\pm 0.27\end{array}$ & $\begin{array}{l}6.72 \\
\pm 0.04\end{array}$ & $\begin{array}{l}6.81 \\
\pm 0.09\end{array}$ & $\begin{array}{l}6.72 \\
\pm 0.04\end{array}$ & $\begin{array}{l}6.78 \\
\pm 0.13\end{array}$ & $\begin{array}{l}6.78 \\
\pm 0.13\end{array}$ & $\begin{array}{l}77.47 \\
\pm 0.93\end{array}$ \\
\hline 5 & GN & $\begin{array}{l}6.94 \\
\pm 0.09\end{array}$ & $\begin{array}{l}6.81 \\
\pm 0.09\end{array}$ & $\begin{array}{l}6.69 \\
\pm 0.27\end{array}$ & $\begin{array}{l}6.97 \\
\pm 0.13\end{array}$ & $\begin{array}{l}6.94 \\
\pm 0.00\end{array}$ & $\begin{array}{l}6.84 \\
\pm 0.13\end{array}$ & $\begin{array}{l}6.84 \\
\pm 0.04\end{array}$ & $\begin{array}{l}78.03 \\
\pm 0.31\end{array}$ \\
\hline & $\mathrm{JN}$ & $\begin{array}{l}7.03 \\
\pm 0.13\end{array}$ & $\begin{array}{l}6.91 \\
\pm 0.04\end{array}$ & $\begin{array}{l}6.66 \\
\pm 0.04\end{array}$ & $\begin{array}{l}6.88 \\
\pm 0.00\end{array}$ & $\begin{array}{l}6.94 \\
\pm 0.09\end{array}$ & $\begin{array}{l}6.91 \\
\pm 0.04\end{array}$ & $\begin{array}{l}6.88 \\
\pm 0.00\end{array}$ & $\begin{array}{r}78.19 \\
\pm 0.09\end{array}$ \\
\hline & GW & $\begin{array}{l}6.63 \\
\pm 0.18\end{array}$ & $\begin{array}{l}6.88 \\
\pm 0.00\end{array}$ & $\begin{array}{l}6.88 \\
\pm 0.18\end{array}$ & $\begin{array}{l}6.84 \\
\pm 0.04\end{array}$ & $\begin{array}{l}6.75 \\
\pm 0.09\end{array}$ & $\begin{array}{l}6.81 \\
\pm 0.09\end{array}$ & $\begin{array}{l}6.78 \\
\pm 0.04\end{array}$ & $\begin{array}{l}77.56 \\
\pm 0.09\end{array}$ \\
\hline & JW & $\begin{array}{l}6.78 \\
\pm 0.22\end{array}$ & $\begin{array}{l}6.91 \\
\pm 0.13\end{array}$ & $\begin{array}{l}6.78 \\
\pm 0.04\end{array}$ & $\begin{array}{l}6.75 \\
\pm 0.18\end{array}$ & $\begin{array}{l}6.59 \\
\pm 0.04\end{array}$ & $\begin{array}{l}6.75 \\
\pm 0.09\end{array}$ & $\begin{array}{l}6.81 \\
\pm 0.18\end{array}$ & $\begin{array}{l}77.38 \\
\pm 0.88\end{array}$ \\
\hline 10 & GN & $\begin{array}{l}7.13 \\
\pm 0.09\end{array}$ & $\begin{array}{l}7.13 \\
\pm 0.18\end{array}$ & $\begin{array}{l}7.03 \\
\pm 0.13\end{array}$ & $\begin{array}{l}7.13 \\
\pm 0.00\end{array}$ & $\begin{array}{l}7.00 \\
\pm 0.00\end{array}$ & $\begin{array}{l}7.06 \\
\pm 0.09\end{array}$ & $\begin{array}{l}7.06 \\
\pm 0.09\end{array}$ & $\begin{array}{l}79.53 \\
\pm 0.57\end{array}$ \\
\hline & $\mathrm{JN}$ & $\begin{array}{l}6.97 \\
\pm 0.22\end{array}$ & $\begin{array}{l}7.06 \\
\pm 0.44\end{array}$ & $\begin{array}{l}7.03 \\
\pm 0.22\end{array}$ & $\begin{array}{l}7.19 \\
\pm 0.44\end{array}$ & $\begin{array}{l}7.06 \\
\pm 0.53\end{array}$ & $\begin{array}{l}7.03 \\
\pm 0.40\end{array}$ & $\begin{array}{l}7.13 \\
\pm 0.53\end{array}$ & $\begin{array}{l}79.47 \\
\pm 2.78\end{array}$ \\
\hline & GW & $\begin{array}{l}6.84 \\
\pm 0.13\end{array}$ & $\begin{array}{l}6.88 \\
\pm 0.27\end{array}$ & $\begin{array}{l}6.88 \\
\pm 0.18\end{array}$ & $\begin{array}{l}6.94 \\
\pm 0.09\end{array}$ & $\begin{array}{l}6.88 \\
\pm 0.09\end{array}$ & $\begin{array}{l}6.88 \\
\pm 0.09\end{array}$ & $\begin{array}{l}6.94 \\
\pm 0.09\end{array}$ & $\begin{array}{l}78.22 \\
\pm 0.40\end{array}$ \\
\hline & JW & $\begin{array}{l}6.91 \\
\pm 0.31\end{array}$ & $\begin{array}{l}6.75 \\
\pm 0.27\end{array}$ & $\begin{array}{l}6.72 \\
\pm 0.04\end{array}$ & $\begin{array}{l}6.81 \\
\pm 0.09\end{array}$ & $\begin{array}{l}6.72 \\
\pm 0.04\end{array}$ & $\begin{array}{l}6.78 \\
\pm 0.13\end{array}$ & $\begin{array}{l}6.78 \\
\pm 0.13\end{array}$ & $\begin{array}{l}77.47 \\
\pm 0.93\end{array}$ \\
\hline 18 & GN & $\begin{array}{l}7.16 \\
\pm 0.04\end{array}$ & $\begin{array}{l}7.06 \\
\pm 0.35\end{array}$ & $\begin{array}{l}6.91 \\
\pm 0.13\end{array}$ & $\begin{array}{l}7.03 \\
\pm 0.22\end{array}$ & $\begin{array}{l}7.00 \\
\pm 0.00\end{array}$ & $\begin{array}{l}6.94 \\
\pm 0.18\end{array}$ & $\begin{array}{l}7.09 \\
\pm 0.22\end{array}$ & $\begin{array}{r}79.19 \\
\pm 1.06\end{array}$ \\
\hline & $\mathrm{JN}$ & $\begin{array}{l}7.00 \\
\pm 0.35\end{array}$ & $\begin{array}{l}6.91 \\
\pm 0.31\end{array}$ & $\begin{array}{l}6.94 \\
\pm 0.27\end{array}$ & $\begin{array}{l}7.03 \\
\pm 0.04\end{array}$ & $\begin{array}{l}6.59 \\
\pm 0.13\end{array}$ & $\begin{array}{l}6.81 \\
\pm 0.27\end{array}$ & $\begin{array}{l}6.91 \\
\pm 0.31\end{array}$ & $\begin{array}{r}78.19 \\
\pm 1.68\end{array}$ \\
\hline & GW & $\begin{array}{l}6.78 \\
\pm 0.22\end{array}$ & $\begin{array}{l}6.72 \\
\pm 0.22\end{array}$ & $\begin{array}{l}6.59 \\
\pm 0.22\end{array}$ & $\begin{array}{l}6.59 \\
\pm 0.31\end{array}$ & $\begin{array}{l}6.72 \\
\pm 0.22\end{array}$ & $\begin{array}{l}6.66 \\
\pm 0.22\end{array}$ & $\begin{array}{l}6.59 \\
\pm 0.22\end{array}$ & $\begin{array}{l}76.66 \\
\pm 1.64\end{array}$ \\
\hline & JW & $\begin{array}{l}6.72 \\
\pm 0.04\end{array}$ & $\begin{array}{l}6.84 \\
\pm 0.22\end{array}$ & $\begin{array}{l}6.81 \\
\pm 0.09\end{array}$ & $\begin{array}{l}6.97 \\
\pm 0.40\end{array}$ & $\begin{array}{l}6.75 \\
\pm 0.35\end{array}$ & $\begin{array}{l}6.81 \\
\pm 0.18\end{array}$ & $\begin{array}{l}6.88 \\
\pm 0.27\end{array}$ & $\begin{array}{l}77.78 \\
\pm 1.55\end{array}$ \\
\hline 20 & GN & $\begin{array}{l}6.75 \\
\pm 0.09\end{array}$ & $\begin{array}{l}6.84 \\
\pm 0.13\end{array}$ & $\begin{array}{l}6.81 \\
\pm 0.09\end{array}$ & $\begin{array}{l}6.88 \\
\pm 0.00\end{array}$ & $\begin{array}{l}6.81 \\
\pm 0.27\end{array}$ & $\begin{array}{l}6.81 \\
\pm 0.18\end{array}$ & $\begin{array}{l}6.84 \\
\pm 0.22\end{array}$ & $\begin{array}{l}77.75 \\
\pm 0.62\end{array}$ \\
\hline & JN & $\begin{array}{l}6.78 \\
\pm 0.04\end{array}$ & $\begin{array}{l}6.63 \\
\pm 0.18\end{array}$ & $\begin{array}{l}6.69 \\
\pm 0.18\end{array}$ & $\begin{array}{l}6.81 \\
\pm 0.09\end{array}$ & $\begin{array}{l}6.72 \\
\pm 0.04\end{array}$ & $\begin{array}{l}6.69 \\
\pm 0.09\end{array}$ & $\begin{array}{l}6.63 \\
\pm 0.18\end{array}$ & $\begin{array}{l}76.94 \\
\pm 0.53\end{array}$ \\
\hline & GW & $\begin{array}{l}6.63 \\
\pm 0.00\end{array}$ & $\begin{array}{l}6.56 \\
\pm 0.18\end{array}$ & $\begin{array}{l}6.69 \\
\pm 0.09\end{array}$ & $\begin{array}{l}6.75 \\
\pm 0.00\end{array}$ & $\begin{array}{l}6.75 \\
\pm 0.35\end{array}$ & $\begin{array}{l}6.66 \\
\pm 0.13\end{array}$ & $\begin{array}{l}6.69 \\
\pm 0.09\end{array}$ & $\begin{array}{l}76.72 \\
\pm 0.84\end{array}$ \\
\hline & JW & $\begin{array}{l}6.66 \\
\pm 0.04\end{array}$ & $\begin{array}{l}6.69 \\
\pm 0.09\end{array}$ & $\begin{array}{l}6.56 \\
\pm 0.09\end{array}$ & $\begin{array}{l}6.66 \\
\pm 0.13\end{array}$ & $\begin{array}{l}6.81 \\
\pm 0.09\end{array}$ & $\begin{array}{l}6.72 \\
\pm 0.04\end{array}$ & $\begin{array}{l}6.69 \\
\pm 0.00\end{array}$ & $\begin{array}{r}77.23 \\
\pm 1.03\end{array}$ \\
\hline Uncontrolled & GN & $\begin{array}{l}6.97 \\
\pm 0.13\end{array}$ & $\begin{array}{l}7.03 \\
\pm 0.31\end{array}$ & $\begin{array}{l}6.88 \\
\pm 0.18\end{array}$ & $\begin{array}{l}7.00 \\
\pm 0.35\end{array}$ & $\begin{array}{l}7.03 \\
\pm 0.22\end{array}$ & $\begin{array}{l}6.97 \\
\pm 0.31\end{array}$ & $\begin{array}{l}6.97 \\
\pm 0.13\end{array}$ & $\begin{array}{r}78.84 \\
\pm 1.64\end{array}$ \\
\hline
\end{tabular}




\begin{tabular}{|c|c|c|c|c|c|c|c|c|c|}
\hline Conditions & $\mathrm{JN}$ & $\begin{array}{l}6.63 \\
\pm 0.18\end{array}$ & $\begin{array}{l}6.59 \\
\pm 0.13\end{array}$ & $\begin{array}{l}6.69 \\
\pm 0.18\end{array}$ & $\begin{array}{l}6.72 \\
\pm 0.13\end{array}$ & $\begin{array}{l}6.59 \\
\pm 0.22\end{array}$ & $\begin{array}{l}6.63 \\
\pm 0.18\end{array}$ & $\begin{array}{l}6.66 \\
\pm 0.22\end{array}$ & $\begin{array}{r}76.50 \\
\pm 1.24\end{array}$ \\
\hline & GW & $\begin{array}{l}6.63 \\
\pm 0.00\end{array}$ & $\begin{array}{l}6.81 \\
\pm 0.09\end{array}$ & $\begin{array}{l}6.84 \\
\pm 0.13\end{array}$ & $\begin{array}{l}6.91 \\
\pm 0.31\end{array}$ & $\begin{array}{l}6.78 \\
\pm 0.22\end{array}$ & $\begin{array}{l}6.78 \\
\pm 0.13\end{array}$ & $\begin{array}{l}6.78 \\
\pm 0.13\end{array}$ & $\begin{array}{l}77.53 \\
\pm 0.84\end{array}$ \\
\hline & JW & $\begin{array}{l}6.69 \\
\pm 0.00\end{array}$ & $\begin{array}{l}6.56 \\
\pm 0.18\end{array}$ & $\begin{array}{l}6.50 \\
\pm 0.27\end{array}$ & $\begin{array}{l}6.53 \\
\pm 0.04\end{array}$ & $\begin{array}{l}6.50 \\
\pm 0.00\end{array}$ & $\begin{array}{l}6.47 \\
\pm 0.04\end{array}$ & $\begin{array}{l}6.44 \\
\pm 0.09\end{array}$ & $\begin{array}{l}76.81 \\
\pm 0.98\end{array}$ \\
\hline
\end{tabular}

Table 4. Correlation between individual parameters. Bold results - correlation coefficient greater than the absolute value of 0.4 and p value<0,05.*3-CQA-3-0-caffeoylquinic acid, 4-CQA-4-0-caffeoylquinic acid, 5-CQA-5-0-caffeoylquinic acid, G-GrainPro, J-jute, Nnatural, W-washed

\begin{tabular}{|c|c|c|c|c|c|c|c|c|}
\hline & Temperature $\left[{ }^{\circ} \mathrm{C}\right]$ & \multirow{2}{*}{$\begin{array}{l}\mathrm{Bag} \\
(\mathrm{G} / \mathrm{J})\end{array}$} & \multirow{2}{*}{$\begin{array}{l}\text { Grain } \\
\text { preparation } \\
(\mathrm{N} / \mathrm{W})\end{array}$} & \multirow[t]{2}{*}{$3-C Q A^{*}$} & \multirow[t]{2}{*}{ 5-CQA* } & \multirow[t]{2}{*}{ 4-CQA* } & \multirow[t]{2}{*}{ Caffeine } & \multirow[t]{2}{*}{ Trigonelline } \\
\hline & $(-10,5,10,18,20, U C)$ & & & & & & & \\
\hline \multirow[t]{2}{*}{ 3-CQA* } & 0.294 & -0.134 & -0.413 & 1.000 & 0.948 & 0.952 & 0.461 & 0.266 \\
\hline & $p=0.163$ & $p=0.532$ & $p=0.045$ & & $p=0.000$ & $p=0.000$ & $p=0.023$ & $p=0.209$ \\
\hline \multirow[t]{2}{*}{$5-\mathrm{CQA}^{*}$} & 0.029 & -0.177 & -0.404 & 0.948 & 1.000 & 0.832 & 0.346 & 0.186 \\
\hline & $p=0.895$ & $p=0.409$ & $p=0.050$ & $p=0.000$ & & $p=0.000$ & $p=0.098$ & $p=0.384$ \\
\hline \multirow[t]{2}{*}{ 4-CQA* } & 0.471 & -0.069 & -0.411 & 0.952 & 0.832 & 1.000 & 0.479 & 0.269 \\
\hline & $p=0.020$ & $p=0.749$ & $p=0.046$ & $p=0.000$ & $p=0.000$ & & $p=0.018$ & $p=0.203$ \\
\hline \multirow[t]{2}{*}{ Caffeine } & 0.352 & -0.004 & 0.458 & 0.461 & 0.346 & 0.479 & 1.000 & 0.932 \\
\hline & $p=0.092$ & $p=0.985$ & $p=0.024$ & $p=0.023$ & $p=0.098$ & $p=0.018$ & & $p=0.000$ \\
\hline \multirow[t]{2}{*}{ Trigonelline } & 0.300 & -0.057 & 0.712 & 0.266 & 0.186 & 0.269 & 0.932 & 1.000 \\
\hline & $p=0.155$ & $p=0.792$ & $p=0.000$ & $p=0.209$ & $p=0.384$ & $p=0.203$ & $p=0.000$ & \\
\hline \multirow[t]{2}{*}{ Aroma } & -0.423 & -0.1680 & 0.550 & -0.246 & -0.150 & -0.414 & 0.265 & 0.405 \\
\hline & $p=0.039$ & $p=0.433$ & $p=0.005$ & $p=0.247$ & $p=0.486$ & $p=0.044$ & $p=0.211$ & $p=0.050$ \\
\hline \multirow[t]{2}{*}{ Flavour } & -0.423 & -0.354 & 0.426 & 0.083 & 0.208 & -0.107 & 0.342 & 0.455 \\
\hline & $p=0.040$ & $p=0.090$ & $p=0.038$ & $p=0.700$ & $p=0.329$ & $p=0.620$ & $p=0.102$ & $p=0.026$ \\
\hline \multirow[t]{2}{*}{ Aftertaste } & -0.190 & -0.345 & -0.396 & 0.296 & 0.356 & 0.152 & 0.523 & 0.571 \\
\hline & $p=0.373$ & $p=0.099$ & $p=0.055$ & $p=0.161$ & $p=0.088$ & $p=0.479$ & $p=0.009$ & $p=0.004$ \\
\hline \multirow[t]{2}{*}{ Acidity } & -0.2358 & -0.261 & 0.548 & 0.094 & 0.177 & -0.077 & 0.415 & 0.549 \\
\hline & $p=0.267$ & $p=0.218$ & $p=0.006$ & $p=0.664$ & $p=0.408$ & $p=0.719$ & $p=0.043$ & $p=0.005$ \\
\hline \multirow[t]{2}{*}{ Body } & -0.3175 & -0.455 & 0.484 & -0.088 & 0.033 & -0.246 & 0.155 & 0.338 \\
\hline & $p=0.131$ & $p=0.026$ & $p=0.016$ & $p=0.683$ & $p=0.879$ & $p=0.246$ & $p=0.469$ & $p=0.106$ \\
\hline \multirow[t]{2}{*}{ Balance } & -0.369 & -0.345 & 0.468 & 0.068 & 0.184 & -0.118 & 0.323 & 0.448 \\
\hline & $p=0.076$ & $p=0.099$ & $p=0.021$ & $p=0.753$ & $p=0.390$ & $p=0.585$ & $p=0.124$ & $p=0.028$ \\
\hline \multirow[t]{2}{*}{ Overall } & -0.300 & -0.307 & 0.475 & 0.137 & 0.219 & -0.035 & 0.432 & 0.535 \\
\hline & $p=0.154$ & $p=0.144$ & $p=0.019$ & $p=0.522$ & $p=0.303$ & $p=0.872$ & $p=0.035$ & $p=0.007$ \\
\hline
\end{tabular}


Table 5. Correlation between analyzed compounds and two first principal components PC1 and PC2. A. In green coffee (GC) and roasted coffee (RC), all analyzed compounds. B. In roasted coffee (RC), all analyzed compounds and sensory attributes. Bold results - loads greater than the absolute value of 0.7 .

\begin{tabular}{|lllll|}
\hline A. Green coffee and roasted coffee & \multicolumn{3}{l|}{ B. } & Roasted coffee \\
\hline Compound & PC1 & PC2 & PC1 & PC2 \\
\hline 3-CQA & $\mathbf{0 , 9 8 4}$ & 0,015 & 0,684 & $-\mathbf{0 , 7 2 4}$ \\
\hline 5-CQA & $\mathbf{0 , 9 7 5}$ & 0,181 & 0,678 & $-0,576$ \\
\hline 4-CQA & $\mathbf{0 , 9 6 5}$ & $-0,248$ & $\mathbf{0 , 7 3 8}$ & $-0,444$ \\
\hline Caffeine & $-\mathbf{0 , 9 9 1}$ & $-0,066$ & $-0,606$ & $\mathbf{0 , 7 4 4}$ \\
\hline Trigonelline & $-\mathbf{0 , 9 9 6}$ & 0,017 & $-\mathbf{0 , 7 2 8}$ & 0,637 \\
\hline Aroma & - & - & $-0,948$ & $-0,310$ \\
\hline Flavour & - & - & $-0,946$ & $-0,322$ \\
\hline Aftertaste & - & - & $-0,944$ & $-0,325$ \\
\hline Acidity & - & - & $-0,948$ & $-0,312$ \\
\hline Body & - & - & $-0,940$ & $-0,334$ \\
\hline Ballance & - & - & $-0,944$ & $-0,328$ \\
\hline Overall & - & - & $-0,946$ & $-0,321$ \\
\hline
\end{tabular}

\section{Figures}


A

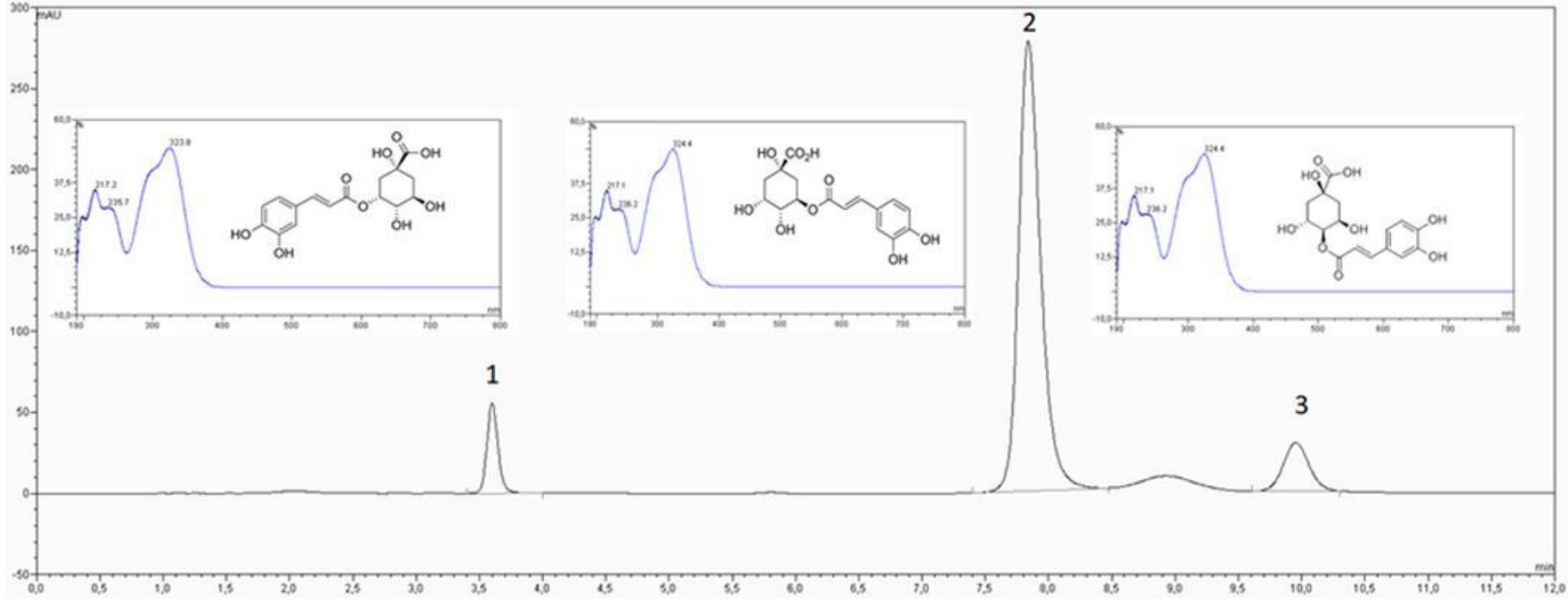

B

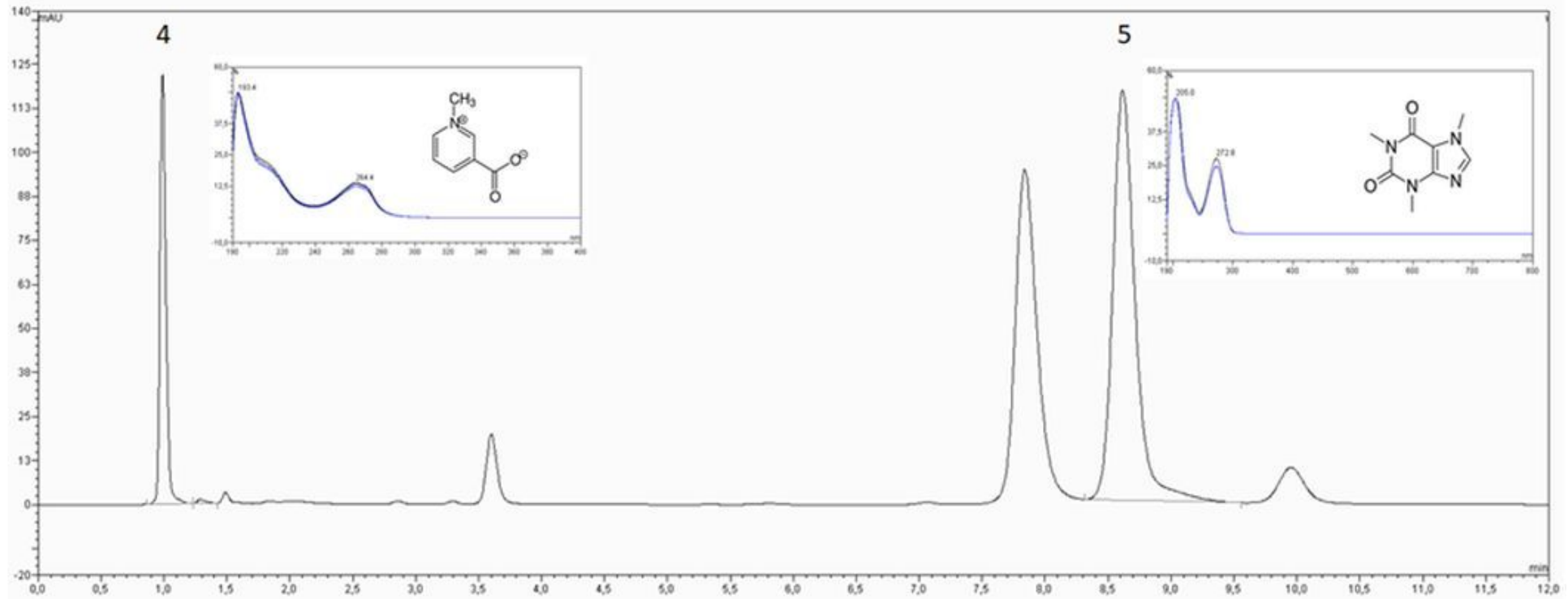

Figure 1

Typical high performance liquid chromatogram of exemplary green coffee extract, indicating the presence of five main ingredients: 1. 5-CQA, 2. 3-CQA, 3. 4-CQA, 4. trigonelline, 5. caffeine. Data collected at two wavelengths: A. $325 \mathrm{~nm}$, B. $272 \mathrm{~nm}$. 


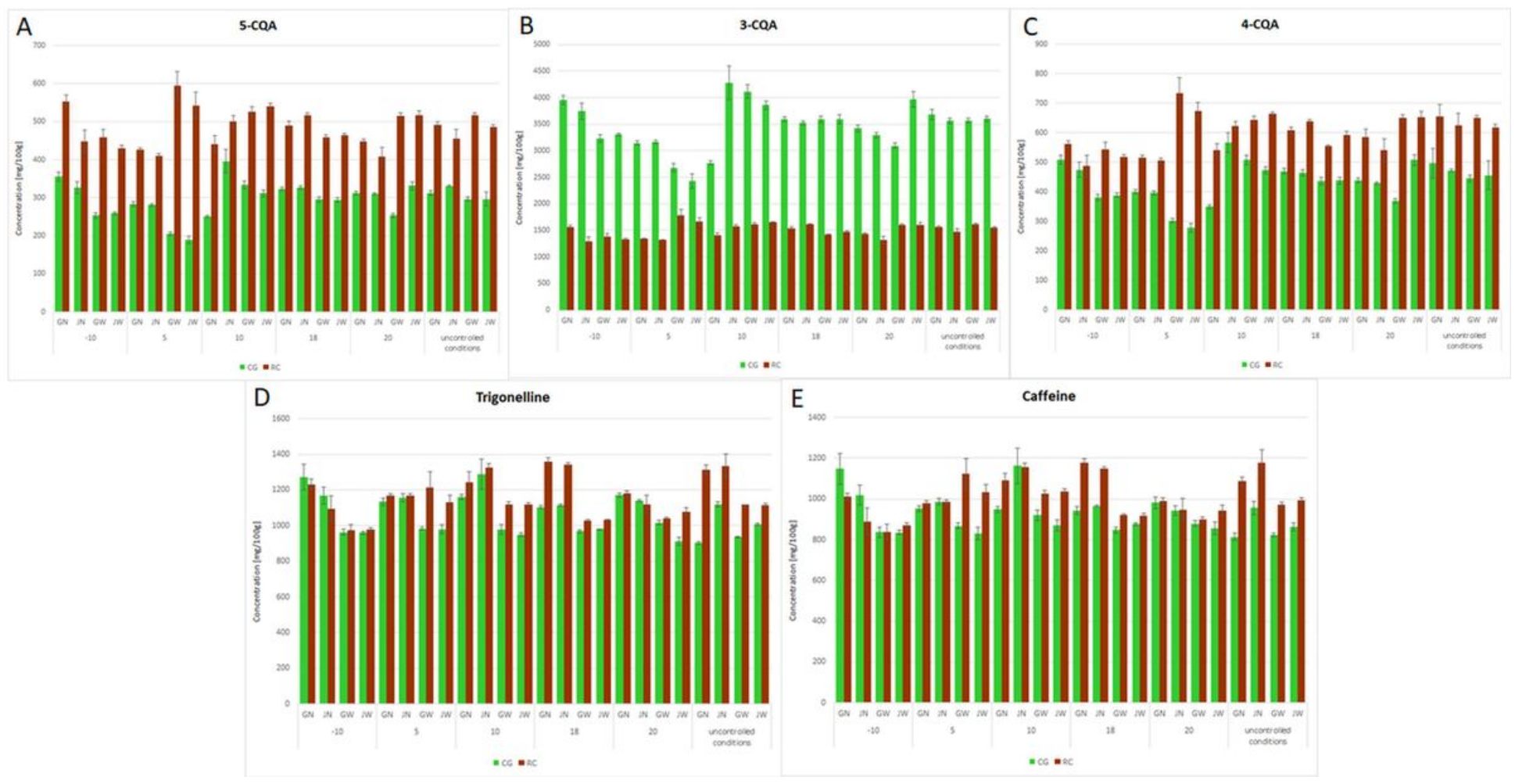

Figure 2

Comparison of compounds found in the green and roasted coffee via HPLC-DAD after 12 months storage, A. 3-CQA, B. 4-CQA, C. 5CQA, D. trigonelline, E. caffeine. Content in $[\mathrm{mg} / 100 \mathrm{~g}]$ as mean from three independent replicates measured in duplicate $(n=6)$. 


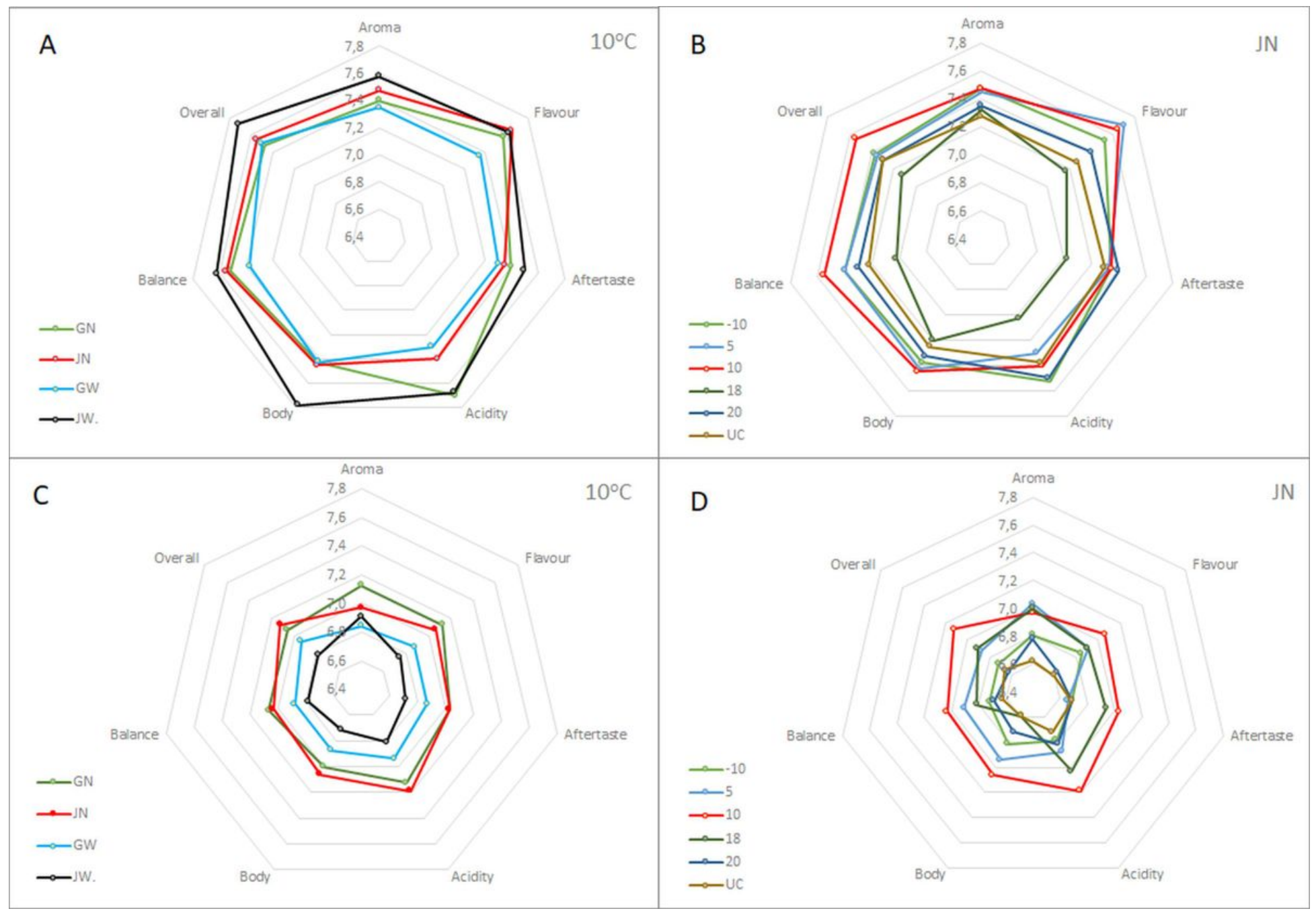

\section{Figure 3}

Sensory profile of coffee samples A. $10 \mathrm{oC}$ chamber on the beginning of sensory evaluation in chambers, B. jute natural bags on the beginning of sensory evaluation in chambers, $C$. $100 \mathrm{C}$ chamber after 12 months storage, D. jute natural bags after 12 months storage. Mean values $(\mathrm{n}=10) \mathrm{GN}$-Grain Pro natural, JN-jute natural, GW-Grain Pro washed, JW-jute washed, storage temperature in oC: - $10,5,10,18,20$, UC-Uncontrolled Conditions.
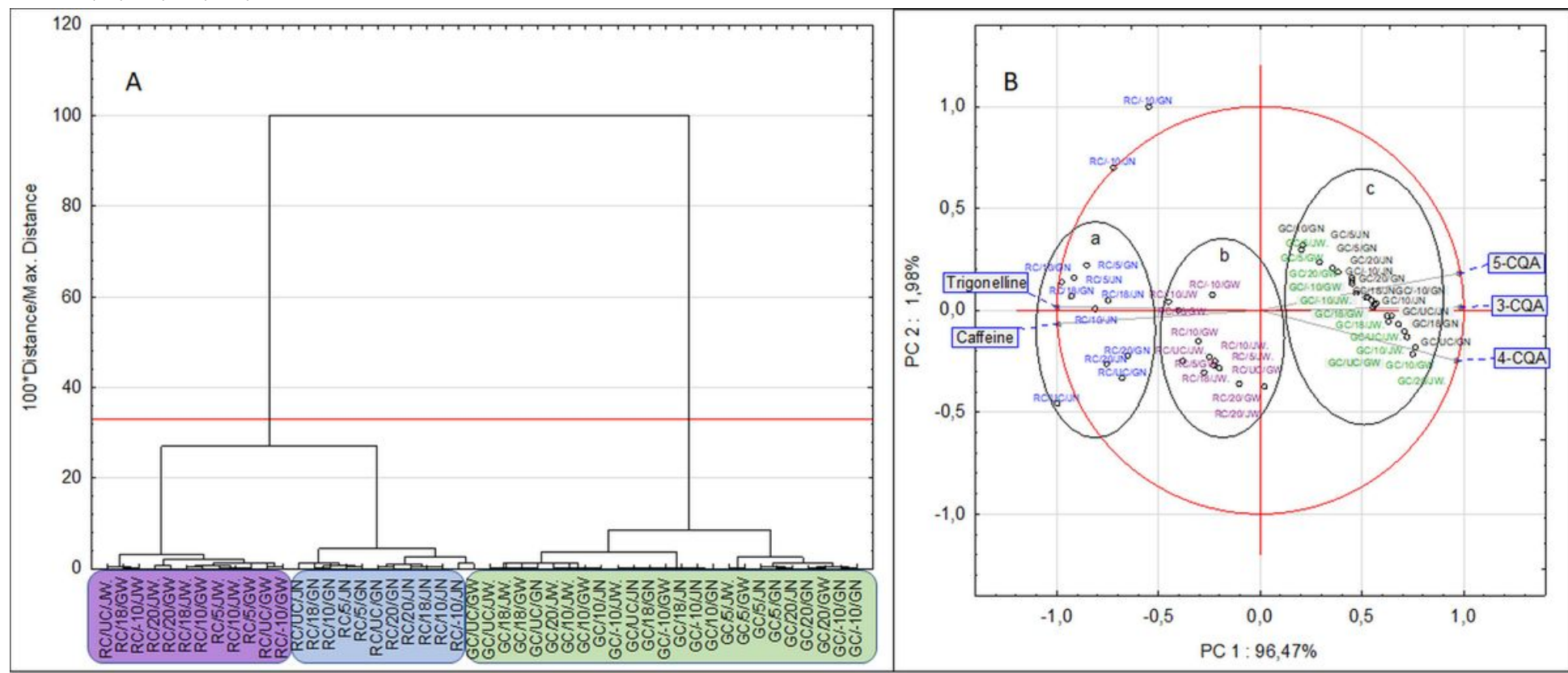

Page $18 / 19$ 
Figure 4

GCs and RCs stored 12 months-chemical discriminants. A. Tree diagram. RC-roasted coffee, GC-green coffee, JN-jute natural, GNGrain-Pro natural, JW-jute washed, GW-Grain-Pro washed, -10, 5, 10, 18, 20oC, UC-uncontrolled conditions. B. Biplot of the projection of variables into the factor plane. Blue dots (a group) represent roasted coffees derived from natural process and stored in Grain Pro and jute. Purple dots (b group) represent roasted coffees derived from washed process and stored in Grain Pro and jute. Green dots (c group) represent green coffees derived from washed process and stored in Grain Pro and jute. Black dots (c group) represent green coffees derived from natural process and stored in Grain Pro and jute. Black names in blue frames represent analyzed compounds such as: 3-CQA-3-0-caffeoylquinic acid, 4-CQA-4-0-caffeoylquinic acid, 5-CQA-5-0-caffeoylquinic acid, caffeine, trigonelline.
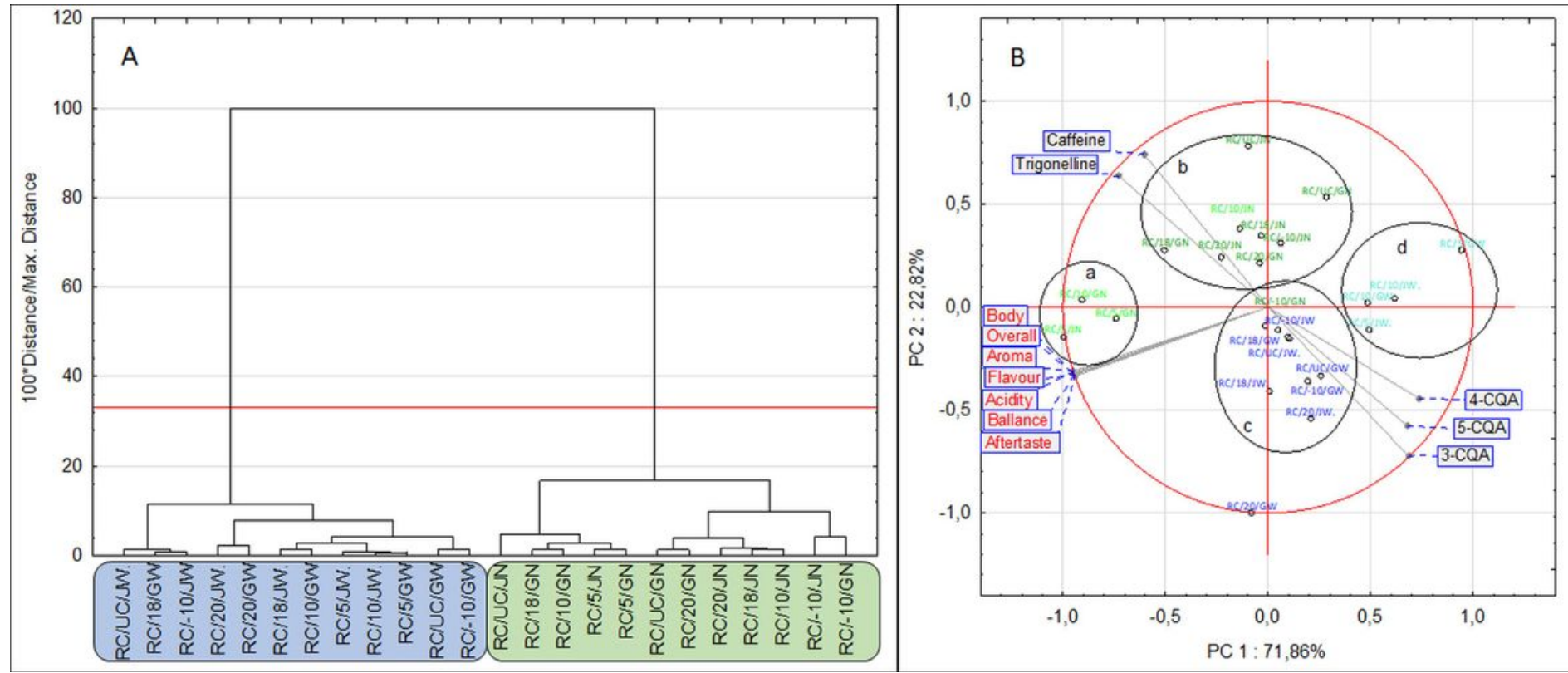

\section{Figure 5}

RCs stored 12 months-chemical and sensory discriminants. A. Tree diagram RC-roasted coffee, GC-green coffee, JN-jute natural, GNGrain-Pro natural, JW-jute washed, GW-Grain-Pro washed, -10, 5, 10, 18, 20oC, UC-uncontrolled conditions. B. Biplot of the projection of variables into the factor plane. Light green dots (a group) represent roasted coffees derived from natural process and stored in Grain Pro and jute in 5 and $10 \mathrm{oC}$ chamber. Dark green dots (b group) represent roasted coffees derived from natural process and stored in Grain Pro and jute in -10, 18, 20oC and UC chamber. Dark blue dots (c group) represent roasted coffee derived from washed process and stored in Grain Pro and jute in -10, 18, 20oC and UC chamber. Light blue dots (d group) represent roasted coffees derived from washed process and stored in Grain Pro and jute in 5 and $100 \mathrm{C}$ chamber. Black names in blue frames represent analyzed compounds: 3-CQA-3-0-caffeoylquinic acid, 4-CQA-4-0-caffeoylquinic acid, 5-CQA-5-0-caffeoylquinic acid, caffeine, trigonelline. Red names in blue frames represent all sensory attributes. 